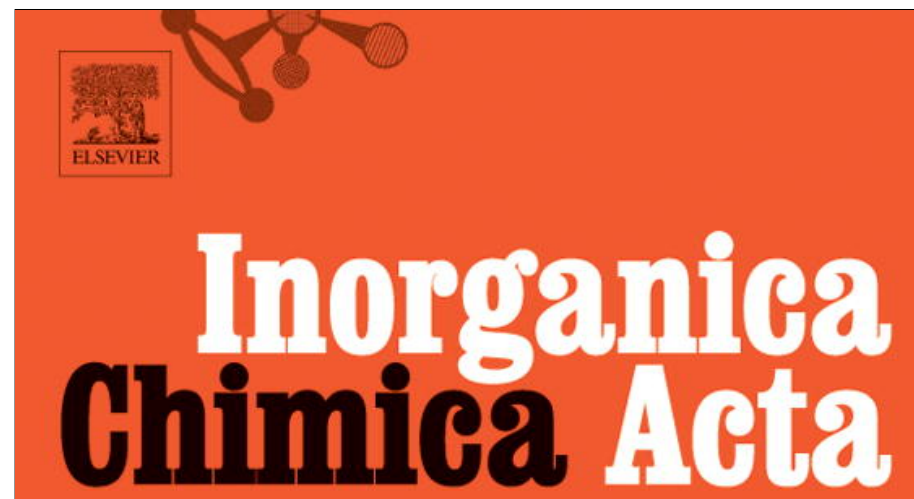

The International Inorganic Chemistry Journal

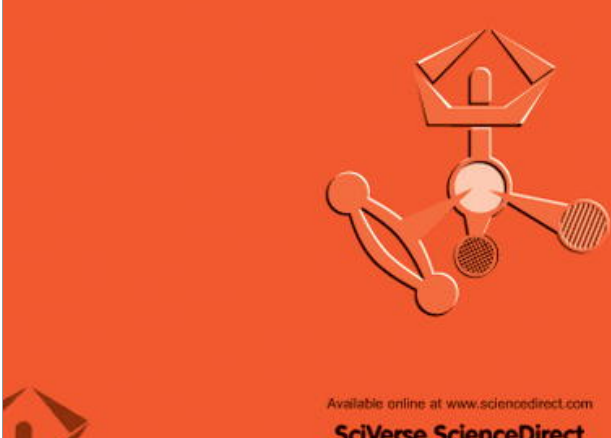

SciVerse ScienceDirect

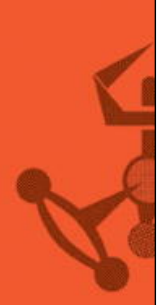

(This is a sample cover image for this issue. The actual cover is not yet available at this time.)

This article appeared in a journal published by Elsevier. The attached copy is furnished to the author for internal non-commercial research and education use, including for instruction at the authors institution and sharing with colleagues.

Other uses, including reproduction and distribution, or selling or licensing copies, or posting to personal, institutional or third party websites are prohibited.

In most cases authors are permitted to post their version of the article (e.g. in Word or Tex form) to their personal website or institutional repository. Authors requiring further information regarding Elsevier's archiving and manuscript policies are encouraged to visit: 


\title{
The interaction between heteroditopic pyridine-nitrogen NHC with novel sulfur NHC ligands in palladium(0) derivatives: Synthesis and structural characterization of a bis-carbene palladium( 0 ) olefin complex and formation in solution of an alkene-alkyne mixed intermediate as a consequence of the ligands hemilability
}

\author{
Luciano Canovese $^{\mathrm{a}, *}$, Fabiano Visentin ${ }^{\text {a }}$, Carlo Levi ${ }^{\mathrm{a}}$, Claudio Santo ${ }^{\text {a }}$, Valerio Bertolasi ${ }^{\mathrm{b}}$ \\ ${ }^{a}$ Dipartimento di Scienze Molecolari e Nanosistemi, Università Ca' Foscari, Venice, Italy \\ ${ }^{\mathrm{b}}$ Dipartimento di Chimica e Centro di Strutturistica Diffrattometrica, Università di Ferrara, Ferrara, Italy
}

\section{A R T I C L E I N F O}

\section{Article history:}

Received 14 February 2012

Received in revised form 4 April 2012

Accepted 10 April 2012

Available online 21 April 2012

\section{Keywords:}

Palladium(0) carbene derivatives

Hetroditopic C-S, C-N carbene ligands

$\mathrm{X}$-ray crystal structures

\begin{abstract}
A B S T R A C T
We have synthesized a new class of heteroditopic chelating ligands bearing the phenylthiomethyl group and variously substituted imidazole derivatives and the corresponding complexes $\left[\mathrm{Pd}\left(\eta^{2}-\mathrm{ma}\right)(\mathrm{R}-\mathrm{NHC}-\right.$ $\mathrm{CH}_{2}-\mathrm{SPh}$ ) (ma = maleic anhydride; $\mathrm{R}=$ methyl, mesityl, di-i-propylphenyl). We have compared their chemical characteristics and reactivity with those of similar palladium( 0$)$ complexes bearing the $\mathrm{R}$ $\mathrm{NHC}-\mathrm{CH}_{2}$-Py ligands.

The hemilability of the above-mentioned moieties is apparent when their palladium derivatives react with an excess of the same or different heteroditopic ligands. In these cases, we obtained complexes bearing maleic anhydride and two mono-coordinated heteroditopic ligands bound to the same metal center. However, at variance with the generally accepted opinion, precipitation of $\mathrm{AgBr}$ does not warrant the quantitative formation of the bis-heteroditopic $\operatorname{Pd}(0)$ derivative and in some cases, a reaction involving a heterogeneous equilibrium is observed.

The reaction of the palladium(0) carbene-sulfur or carbene-nitrogen complexes with the alkyne dimethyl-2-butynedioate (dmbd) to give palladacyclometallate derivatives is not always warranted and formation of the intermediate $\left[\mathrm{Pd}\left(\eta^{2}-\mathrm{ma}\right)\left(\eta^{2}-\mathrm{dmdb}\right)\left(\kappa^{1}-\mathrm{Mes}-\mathrm{NHC}-\mathrm{CH}_{2}-\mathrm{SPh}\right)\right]$ is detected only in one case.

Finally, we have carried out a diffractometric study on the solid-state structures of two derivatives and in particular we describe the configurations of the complex $\left[\mathrm{Pd}\left(\eta^{2}-\mathrm{ma}\right)\left(\kappa^{1}-\mathrm{Me}-\mathrm{NHC}-\mathrm{CH}_{2}-\mathrm{SPh}\right)_{2}\right]$ and of $\left[\mathrm{Pd}\left(\eta^{2}-\mathrm{ma}\right)\left(\mathrm{Me}-\mathrm{NHC}-\mathrm{CH}_{2}-\mathrm{SPh}\right)\right]$.

(c) 2012 Elsevier B.V. All rights reserved.
\end{abstract}

\section{Introduction}

Catalysts should be simultaneously characterized by a remarkable stability, a high reactivity and finally by selectivity toward the formation of the reaction products. These peculiarities which somehow might be considered chemically in conflict should all be present when metal complexes bearing hemilabile ligands [1] are used as catalysts. As a matter of fact, the introduction of a labile terminus into chelating ligands should promote the activation of a specific geometric site while the stability and the electronic requirements of the related complexes should be warranted by the pivot, which is the strong coordinating part of the ligands. The dangling wing bearing the labile nucleophile plays an impor-

\footnotetext{
* Corresponding author.

E-mail address: cano@unive.it (L. Canovese).
}

tant role as well, since it will restore the starting substrates by re-coordinating the site made vacant as a consequence of the catalytic activity of the complexes [2].

Several classes of complexes of different metals and hemilabile ligands with a number of different scaffolds, different pivots and labile donors were synthesized and recently reviewed [2,3]. Furthermore, after the seminal article by Arduengo [4] a novel class of the performing donor ligands NHC was available for the chemists' community and hence several new heteroditopic and hemilabile $N H C-E(E=P, N, O)$ ligands soon appeared in the literature [5]. Owing to our interest on chelating ligands bearing thioetheric sulfur [6] and the scarcity of heteroditopic NHC-S spectator ligands in the literature [7], we have synthesized some phenyl-thiomethylcarbene ( $\mathrm{R}-\mathrm{NHC}-\mathrm{CH}_{2}-\mathrm{SPh}$ ) ( $\mathrm{R}=$ methyl, mesityl, di-i-propylphenyl) derivatives and the corresponding low valent palladium complexes and have compared their chemical characteristics and reactivity 
with those of the more studied R-NHC- $\mathrm{CH}_{2}$-Py palladium(0) compounds [8].

Moreover, we have carried out a diffractometric study on the solid state structures of two olefin complexes and in particular we describe the configuration of a complex bearing maleic anhydride, Mes- $\mathrm{NHC}-\mathrm{CH}_{2}$-Py and Me- $\mathrm{NHC}-\mathrm{CH}_{2}-\mathrm{SPh}$ ligands coordinated to the same metal center.

\section{Result and discussion}

\subsection{Synthesis of imidazolium bromide derivatives}

The synthesis of the $N$-methylimidazolium (1a and $\mathbf{2 a}$ ) and $\mathrm{N}$-arylimidazolium salts $(\mathbf{1 b}, \mathbf{1 c}, \mathbf{2 b}$ and $\mathbf{2 c}$ ) was easily achieved in good yield (70-94\%) by reacting 1-(2,4,6-trimethylphenyl) imidazole, 1-(2,6-di-i-propylphenyl)imidazole [9] or commercial 1-methylimidazole with an almost equimolecular amount of chloromethylphenylthioether or chloromethylpyridine in anhydrous acetonitrile in the presence of $\mathrm{KBr}$, according to the literature procedure (Scheme 1): [10].

The formation of the imidazolium salts was easily detected by ${ }^{1} \mathrm{H}$ and ${ }^{13} \mathrm{C}$ NMR technique owing to the very low field resonance of the acid imidazole proton between 10.0 and 10.5 and of the imidazole carbon between 136 and $139 \mathrm{ppm}$. Notably, compounds 2b and 2c which are known were synthesized by means of a slightly different procedure from that reported in the literature [11] (see Section 4).

\section{2. $\mathrm{R}-\mathrm{NHC}-\mathrm{CH}_{2}-\mathrm{SPh}$ and $\mathrm{R}-\mathrm{NHC}-\mathrm{CH}_{2}-\mathrm{Py}$ silver(I) complexes}

The transmetalation protocol with silver(I) NHC derivatives represents an advantageous and general synthetic procedure for the obtainment of transition metal carbene substrates [5g,5h,11]. As a matter of fact, the stability of silver carbene complexes does not require particular precautions and the synthesis of the corresponding transition metal carbene substrates has usually a remarkable yield. In particular, the transmetalation between silver(I) NHC derivatives and palladium(0) olefin precursors represents a very efficient synthetic approach to palladium(0) carbene complexes [5e,5j,7e,11b,11c,12]. Thus, we have synthesized the silver(I) NHC substrates according to the method reported in the literature [5g,5h] and described in Scheme 2.

The disappearance of the solid $\mathrm{Ag}_{2} \mathrm{O}$ marks the reaction progress, whereas the ${ }^{1} \mathrm{H}$ and ${ }^{13} \mathrm{C}$ NMR spectra of the products confirm the formation of the title complexes. In particular, the acid imidazolium proton is no more detectable in the NMR spectra of the silver derivatives and the coordinated imidazole carbon resonates at about $180 \mathrm{ppm}$. Remarkably, the methylene groups $\underline{\mathrm{CH}}_{2}$-Py or $\mathrm{CH}_{2}-\mathrm{S}$ resonate as singlets thanks to the monocoordination of the $\mathrm{R}-\mathrm{NHC}-\mathrm{CH}_{2}-\mathrm{Py}$ or $\mathrm{R}-\mathrm{NHC}-\mathrm{CH}_{2}-\mathrm{SPh}$ and the consequent free rotation of the dangling uncoordinated wing bearing the thioether or pyridine fragment.

\subsection{Synthesis of $\left[\mathrm{Pd}\left(\eta^{2}-\mathrm{ol}\right)(\mathrm{NHC})\right]$ complexes}

Taking advantage of the lability of COD, Cavell and co-workers proposed the reaction between $\left[\mathrm{Pd}\left(\eta^{2}-\mathrm{ma}\right)(\mathrm{COD})\right]$ and free monodentate NHC ligands for the synthesis of some novel palladium(0) carbene derivatives [12]. However, such a direct approach is not possible with our carbene ligands since they are not available as free species. Therefore, we have reacted the same palladium $(0)$ precursor with the silver derivatives $\mathrm{R}-\mathrm{NHC}-\mathrm{CH}_{2}-\mathrm{PyAgBr}$ or R$\mathrm{NHC}-\mathrm{CH}_{2}-\mathrm{SPhAgBr}$. In order to minimize the decomposition of $\left[\mathrm{Pd}\left(\eta^{2}-\mathrm{ma}\right)(\mathrm{COD})\right]$, we have carried out the reaction by mixing the reactants at $253 \mathrm{~K}$. The gradual temperature increase to $273 \mathrm{~K}$ promotes the reaction progress and the separation of the heteroditopic palladium $(0)$ carbene complexes upon filtration of $\mathrm{AgBr}$ (Scheme 3).

However, a limitation of such a method is represented by the fact that the ensuing carbene derivatives can only bear maleic anhydride (ma) or tetracyanoethene (tcne) since low valent palladium COD complexes with other, even slightly less stabilizing olefins are unstable and immediately decompose. The alternative approach to obtaining palladium(0) olefin complexes of the type $\left[\operatorname{Pd}\left(\eta^{2}-\mathrm{ol}\right)\left(\mathrm{L}^{-\mathrm{L}^{\prime}}\right)\right]$ (ol = ma, fn, tcne; L-L' = NHC-Nitrogen) proposed by Elsevier and co-workers, consisting in the reaction between

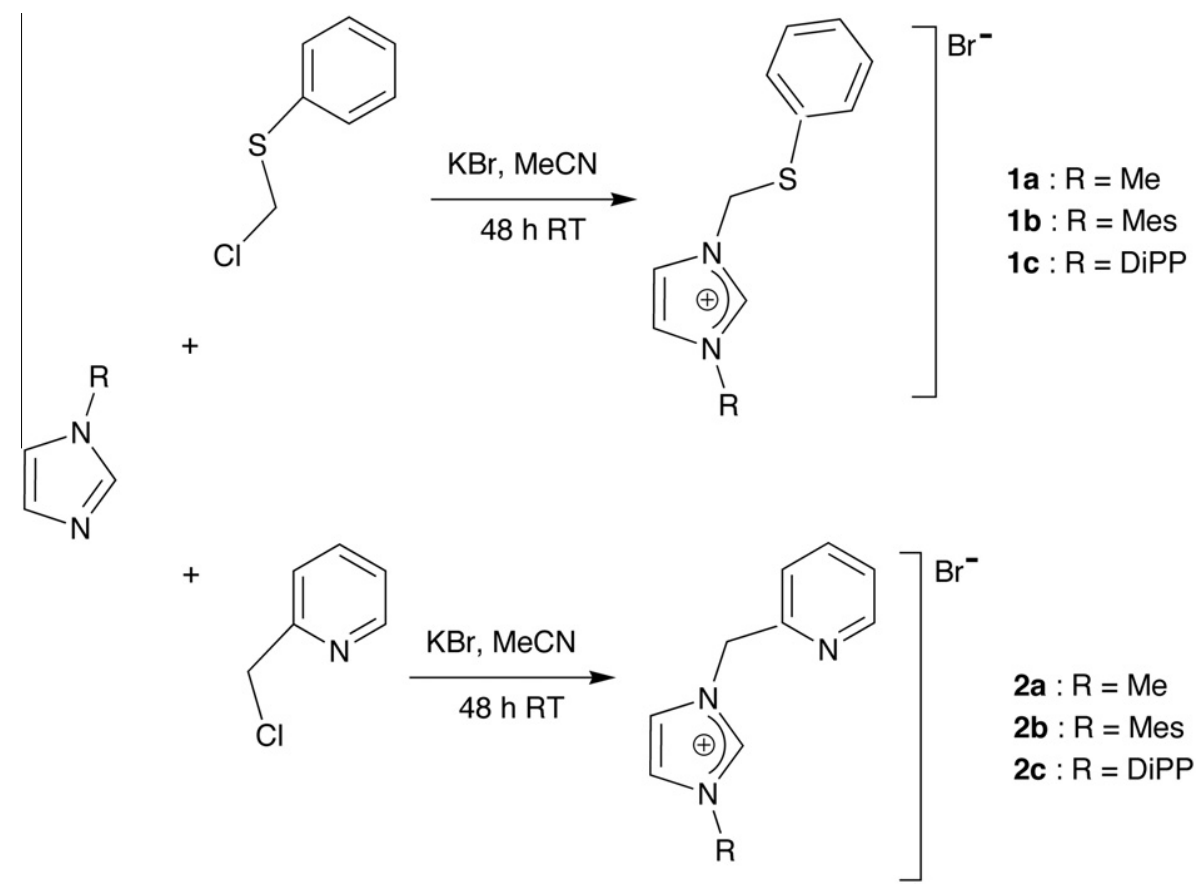

Scheme 1. Synthetic methodology for the preparation of compounds $1 \mathbf{a}-\mathbf{1 c}$ and $\mathbf{2 a - 2 c}$. 


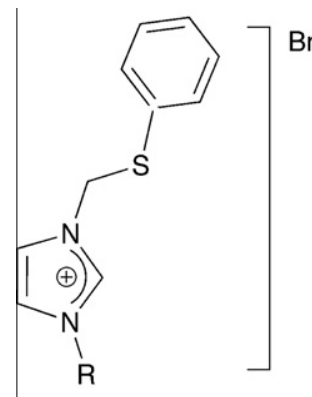<smiles></smiles>

3a: $\mathrm{R}=\mathrm{Me}$

3b : $R=$ Mes

3c $: R=\operatorname{DiPP}$<smiles></smiles><smiles></smiles>

$4 a: R=M e$

4b $: R=$ Mes

$\mathbf{4 c}: \mathrm{R}=\mathrm{DiPP}$

Scheme 2. Synthetic methodology for the preparation of compounds $3 a-3 c$ and $\mathbf{4 a}-\mathbf{4 c}$<smiles></smiles><smiles></smiles>

5a : $\mathrm{R}=\mathrm{Me}$

$5 b: R=$ Mes

$5 c: R=\operatorname{DiPP}$

$\left[\mathrm{Pd}\left(\eta^{2}-\mathrm{ma}\right)(\mathrm{COD})\right]$<smiles></smiles>

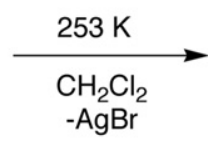<smiles></smiles>

$6 a: R=M e$

$6 \mathbf{b}: \mathrm{R}=$ Mes

Scheme 3. Synthetic methodology for the preparation of compounds $\mathbf{5 a - 5 c}$ and $\mathbf{6 a}, \mathbf{6 b}$.

the complexes $\left[\operatorname{Pd}\left(\eta^{2}-o l\right)(t-B u D A B)\right](o l=m a, f n, t c n e, t-B u D A B=$ $N, N^{\prime}$-di-t-butyl-1,4-diaza-1,3-butadiene) and the silver carbene derivatives $\mathrm{NHC}-\mathrm{NMe}_{2} \mathrm{AgBr}[5 \mathrm{~g}], \quad \mathrm{NHC}$-pyridylAgBr, NHC-picolylAgBr (ol = ma) [11c] and $N H C$-pyrimidylAgBr (ol = ma) [13b], suggested to us an alternative protocol. Thus, we have reacted the NHC silver(I) derivatives with complexes of the type $\left[\mathrm{Pd}\left(\eta^{2}-\mathrm{ol}\right)(\mathrm{MeN}-\mathrm{SPh})\right](\mathrm{ol}=\mathrm{ma}$, nq, tmetc; MeN-SPh = 2-methyl6-sulfanylmethyl-pyridine) [14], the spectator ligand of which is displaced very easily by several nucleophiles [14b]. Thus, we were able to obtain the complexes of type $\left[\mathrm{Pd}\left(\eta^{2}-\mathrm{ol}\right)\left(\mathrm{R}-\mathrm{NHC}-\mathrm{CH}_{2}-\mathrm{Py}\right)\right]$ (ol = nq, tmetc) (Scheme 4):

Apparently, the complex $\left[\mathrm{Pd}\left(\eta^{2}-\mathrm{ol}\right)(\mathrm{MeN}-\mathrm{SPh})\right]$ is more stable than $\left[\operatorname{Pd}\left(\eta^{2}-\mathrm{ma}\right)(\mathrm{COD})\right]$, thus the exchange reaction based on it can be carried out at RT. However, addition of R-NHC- $\mathrm{CH}_{2}-\mathrm{SPh}-$ $\mathrm{AgBr}$ to a solution of pyridylthioether palladium( 0 ) derivatives leads to the formation of an equilibrium mixture of differently substituted species. This fact seems to suggest that the chelating ligands R-NHC- $\mathrm{CH}_{2}-\mathrm{SPh}$ are less efficient than R-NHC-CH -Py in displacing the pyridylthioether fragment.

The formation of the heteroditopic carbene olefin complexes can be clearly deduced from their ${ }^{1} \mathrm{H}$ and ${ }^{13} \mathrm{C}$ NMR spectra. In particular, the olefin protons and carbons resonate at higher fields than those of the uncoordinated ma $(\Delta \delta \sim 3-4$ and $\sim 100 \mathrm{ppm}$, respectively).

In the low temperature $(253 \mathrm{~K}){ }^{1} \mathrm{H}$ NMR spectra of the complexes bearing ma and $\mathrm{R}-\mathrm{NHC}-\mathrm{CH}_{2}-\mathrm{SPh}(\mathbf{5 a}-\mathbf{5 c})$, the olefin protons 


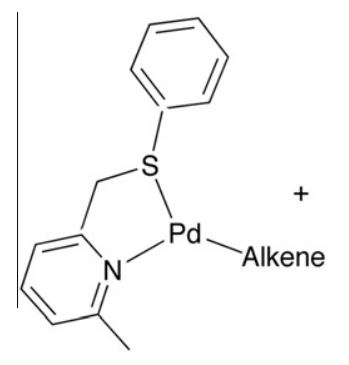<smiles></smiles><smiles></smiles>

7a $: R=$ Me; Alkene = napthoquinone
7b $: R=$ Mes; Alkene = napthoquinone
7c $: R=$ DiPP; Alkene=napthoquinone
8a $: R=$ Me; Alkene = tetramethyl ethene tetracarboxylate
8b $: R=$ Mes; Alkene =tetramethyl ethene tetracarboxylate
8c $: R=$ DiPP; Alkene=tetramethyl ethene tetracarboxylate

Scheme 4. Synthetic methodology for the preparation of compounds $7 \mathbf{a}-\mathbf{7 c}$ and $\mathbf{8 a - 8 c}$.

always resonate as two doublets as a consequence of the asymmetry of the spectator ligands. Consistently, at the same temperature the olefin carbons show up as two separated signals.

At RT the olefin protons coalesce into two broad singlets. Such a phenomenon was often attributed to an apparent olefin rotation consisting in the de-coordination of the thioether wing followed by ligand rotation about the $\mathrm{Pd}-\mathrm{C}$ bond and re-coordination at the opposite side (T-shape-Y-shape-T-shape mechanism). However, an alternative associative way triggered by the free electron pair on the $\mathrm{sp}^{3}$ sulfur, cannot be ruled out [15].

Despite their diasterotopic nature at RT the $\mathrm{CH}_{2}-\mathrm{S}$ protons resonate as a broad singlet. This not unprecedented phenomenon is probably due to inversion of the sulfur absolute configuration due to fast exchange between the coordinated and the uncoordinated doublet of $\mathrm{sp}^{3}$ sulfur [6a and refs. therein]. At low temperature $(223 \mathrm{~K})$, the broad singlet of complex $\mathbf{5 c}$ only splits into an $A B$ system.

The ${ }^{1} \mathrm{H}$ NMR spectra of the complexes $\mathbf{5 b}$ and $\mathbf{5 c}$ at $253 \mathrm{~K}$ display the net separation of the signals ascribable to the ortho methyl protons of the mesityl and di-i-propylphenyl fragments, indicating that the rotation of those groups about their bond with the imidazole nitrogen is hampered.

In agreement with previous findings [11c] the carbenic carbons signal that is observed between 188.1 and 192.5 ppm exhibits a low field shift as compared to that of the $\mathrm{Ag}(\mathrm{I})$ complexes.

Finally, it is noteworthy that the resolved solid state structure of complex 5b confirms the observation reported above (vide post).

Also in the case of the complexes bearing R-NHC-CH -Py and naphthoquinone $(\mathbf{7 a - 7 c})$ the olefin protons are detected as broad singlet in the RT ${ }^{1} \mathrm{H}$ NMR spectra. However, this signal splits into two separated signals at $253 \mathrm{~K}$.

Owing to the ring inversion of the chelating ligand (olefin apparent rotation) the $\mathrm{CH}_{2}$-Py protons which are detected as an $\mathrm{AB}$ system at $253 \mathrm{~K}$ broaden at RT [11c].

The $\mathrm{OC}_{3}$ protons of the tetramethylethene tetracarboxylate derivatives $(\mathbf{8 a}-\mathbf{8 c})$ are detected at RT as two singlets. Probably, due to the steric hindrance in the complexes no olefin apparent rotation is operative in these cases.

\subsection{Synthesis of bis-carbene palladium(0) olefin complexes}

Taking advantage of the hemilability of these heteroditopic ligands, we have explored the possibility of introducing another carbene into the molecular scaffold of the palladium(0) olefin derivatives. Mc Guiness and Cavell [8a], Frøseth [16] and Fliedel and Braunstein [17] have obtained trans or cis bis-carbene derivatives by reacting the $\mathrm{Pd}(\mathrm{II})$ cyclo-octadiene substrates $[\mathrm{Pd}(\mathrm{COD})(\mathrm{R}) \mathrm{Cl}],\left[\mathrm{Pd}(\mathrm{COD}) \mathrm{Cl}_{2}\right]$ or $\left[\mathrm{Pd}(\mathrm{NCMe})_{4}\right]\left(\mathrm{BF}_{4}\right)_{2}$ with the silver complexes of heteroditopic carbene-pyridine, carbene-imine or carbene-thioether respectively. Moreover, palladium(0) complexes bearing two monocoordinating carbene and maleic anhydride or tetracyanoethene have appeared so far in the literature $[12,18]$. However, attempts to synthesize complexes bearing two different heteroditopic carbenes simultaneously coordinated to low valent palladium were never carried out.

Therefore, we have reacted the palladium $(0)$ derivative $\mathbf{5 a}$ with the silver(I) complex $\mathbf{4 b}$ in $\mathrm{CH}_{2} \mathrm{Cl}_{2}$ at $\mathrm{RT}$. The ensuing fast reaction yields quantitatively the complex 9 represented in Chart 1 . The structure of complex $\mathbf{9}$ in solution is deduced from its NMR spectra and confirmed by a diffractometric study. In particular, the concomitant coordination of both carbenes is testified by the presence of two distinct carbene carbon signals at 189.2 and $189.3 \mathrm{ppm}$ in the ${ }^{13} \mathrm{C}$ NMR spectrum whereas the coordination of maleic anhydride is confirmed by the presence of two doublets of the olefin protons at 3.27 and $3.33 \mathrm{ppm}$ in the ${ }^{1} \mathrm{H}$ NMR spectrum. Curiously, the $\mathrm{CH}_{2}-\mathrm{Py}$ and $\mathrm{CH}_{2}-\mathrm{S}$ protons resonate as two $\mathrm{AB}$ systems although the sulfur and nitrogen are not bound to the metal center. This is probably due to the crowded molecular structure which hampers every rearrangement of the ligands, as can also be deduced from the hindered rotation of the mesityl ring about the $\mathrm{C}-\mathrm{N}$ bond. As already stated, the mono-crystal diffractometric study of complex $\mathbf{9}$ confirms the proposed structure (vide post, Fig. 5a).

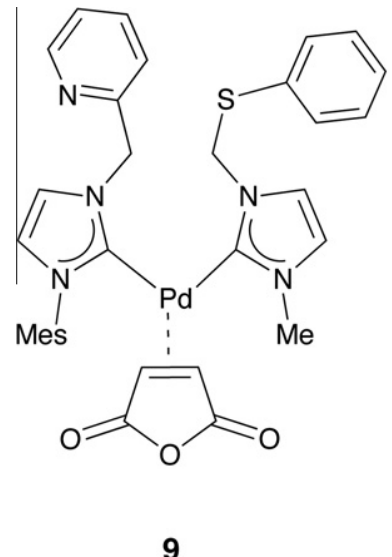<smiles></smiles>
10

Chart 1. Topological representation of the complexes $\mathbf{9}$ and $\mathbf{1 0}$ bearing the two monocoordinated ditopic carbenes and the olefin ma coordinated to palladium. 
In order to verify the general validity of such a protocol we have reacted palladium $(0)$ and silver(I) complexes bearing the same carbene ligand. Thus, we have studied the reaction of the complex $\mathbf{5 a}$ in $\mathrm{CD}_{2} \mathrm{Cl}_{2}$ with an equimolecular amount of the silver derivative $\mathbf{3 a}$ by ${ }^{1} \mathrm{H}$ NMR at $298 \mathrm{~K}$. Again, we have observed the fast and quantitative formation in solution of a new compound which was identified as complex $\mathbf{1 0}$ and isolated by addition of diethyl ether (Chart 1 ).

Surprisingly, the reaction between complexes $\mathbf{6 b}$ and $\mathbf{4 b}$ is not quantitative and is better represented by an equilibrium involving the incomplete displacement of the pyridine nitrogen of the coordinated ligand Mes-NHC-Py by the carbene carbon of the same ligand despite the commonly accepted idea that precipitation of insoluble $\mathrm{AgBr}$ should in any case drive this kind of reactions to completion. As a consequence, the contemporary presence in solution of $\mathbf{6 b}, \mathbf{4 b}$ and 11 is clearly observed in the ensuing NMR spectrum whereas solid $\mathrm{AgBr}$ is detected as a cloudy suspension (Chart 2; Fig. 1).

Addition to the solution of further amounts of $\mathbf{4 b}$ confirms the equilibrium nature of the reaction which can be easily driven to completion by addition of three equivalent of the silver derivative.

Similar equilibrium distributions can also be detected in the case of the reaction between complexes $\mathbf{6 a}$ with $\mathbf{4 a}$ and $\mathbf{6 a}$ with $\mathbf{4 b}$ (or $\mathbf{6 b}$ with $\mathbf{4 a}$ ). It is apparent that the equilibrium position for these reactions is essentially determined by the insolubility of $\mathrm{AgBr}$ which dissolves in $\mathrm{CH}_{2} \mathrm{Cl}_{2}$ in an almost negligible extent, and by the efficiency of the carbene as strong $\sigma$-donor. These two concomitant phenomena support the widespread idea that these reactions are always quantitative. We have however shown that the chelating effect can efficiently contrast the reaction progress, and when two R-NHC- $\mathrm{CH}_{2}$-Py carbene ligands are involved at the same time, the reaction is not completely shifted to the right. At variance, these reactions are quantitative when at least one heteroditopic R-NHC- $\mathrm{CH}_{2}$-SPh carbene is involved. Evidently, the coordinative capability of the phenyl substituted sulfur appears to be less effective than that of the pyridine nitrogen, [6].

\subsection{Reaction of the palladium(0) carbene derivatives with dimethyl-2- butynedioate (dmbd)}

We have also studied the attack of the activated alkyne dimethyl-2-butynedioate (dmbd) on the complexes $\left[\operatorname{Pd}\left(\eta^{2}-m a\right)\right.$ $\left.\left(\mathrm{R}-\mathrm{NHC}-\mathrm{CH}_{2}-\mathrm{Py}\right)\right]$ and $\left[\mathrm{Pd}\left(\eta^{2}-\mathrm{ma}\right)\left(\mathrm{R}-\mathrm{NHC}-\mathrm{CH}_{2}-\mathrm{SPh}\right)\right]$. As can be deduced from the ${ }^{1} \mathrm{H}$ and ${ }^{13} \mathrm{C}$ NMR spectra, the complex $6 \mathbf{a}$ reacts at RT with dmbd in $\mathrm{CD}_{2} \mathrm{Cl}_{2}$ giving quantitatively the palladium(II) cyclopentadienyl derivative $\left[\mathrm{Pd}\left(\mathrm{Me}-\mathrm{NHC}-\mathrm{CH}_{2}-\mathrm{Py}\right)\left(\mathrm{C}_{4}(\mathrm{COOMe})_{4}\right)\right]$
12. The presence of four distinct $\mathrm{OCH}_{3}$ signals at $3.40,3.42,3.68$ and $3.73 \mathrm{ppm}$ and of the displaced maleic anhydride at about $7 \mathrm{ppm}$ testifies the formation of the metallacyclopentadienyl derivative (Fig 2). Consistently, the carbene carbon signal shifts from $188.1 \mathrm{ppm}$ of the starting complex $\mathbf{6 a}$ to $180.5 \mathrm{ppm}$ (see Section 4).

On the contrary, when complexes $\mathbf{5 a}, \mathbf{5 b}$ and $\mathbf{6 b}$ react with dmbd, an extensive decomposition with concomitant formation of metallic palladium was observed. In order to explain such a different behavior we resorted to an NMR study of the reaction between 5b and the alkyne dmbd at low temperature $\left(\mathrm{CD}_{2} \mathrm{Cl}_{2} ; 253 \mathrm{~K}\right)$. The formation of a new organometallic species was immediately observed. The detailed investigation of its ${ }^{1} \mathrm{H}$ NMR spectrum strongly suggests that the derivative $\left[\operatorname{Pd}\left(\eta^{2}-\mathrm{ma}\right)\left(\eta^{2}-\mathrm{dmdb}\right)\left(\kappa^{1}-\mathrm{Mes}-N H C\right.\right.$ $\mathrm{CH}_{2}-\mathrm{SPh}$ )] (13) bearing ma, dmbd and the monocoordinate carbene bound to palladium $(0)$ is formed (Chart 3 ).

As a matter of fact, the olefin protons of the $\eta^{2}$-coordinated ma resonate as a couple of doublets at 4.02 and $4.51 \mathrm{ppm}$ $\left(J_{\mathrm{HH}}=4.5 \mathrm{~Hz}\right)$, whereas the coordinated dmbd displays two singlets ascribable to the methyl protons of the non-equivalent methoxy fragments at 3.70 and $3.96 \mathrm{ppm}$, respectively. Interestingly, owing to the asymmetry of the intermediate, the $\mathrm{CH}_{2}-\mathrm{S}$ protons resonate as an $A B$ system irrespective of the fact that the sulfur remains uncoordinated. This is probably due to the crowded molecular structure of $\mathbf{1 3}$ which hampers the free rotation of the wing bearing the thioether fragment, as was observed in the case of complex 9, the open structure of which was unambiguously determined. Moreover, no uncoordinated ma is detectable in solution and the methyl groups of the mesityl fragment resonate as three distinct singlets since the free rotation of the latter is also hampered by steric hindrance (Fig. 3).

The HMQC spectrum confirms such an interpretation (see Supplementary material, Fig. 1SI); in particular, the coordination of the olefin ma is evident thanks to the cross-peaks between the olefin carbons $(61.8,62.8 \mathrm{ppm})$ and the olefin protons $(4.02,4.51 \mathrm{ppm})$ and to the signal resonance at lower field than that of the corresponding starting olefin complex.

Further confirmation comes from the presence of the olefin carbonyl carbon resonances at 168.4 and $168.7 \mathrm{ppm}$, the signal of the coordinated carbene carbon at $180.9 \mathrm{ppm}$ and those of the nonequivalent esteric carbons of the coordinated dmbd fragment at 159.8 and $160.8 \mathrm{ppm}$, respectively.

In some respect the compound $\mathbf{1 3}$ reminds similar species bearing two olefins and one NHC ligand coordinated to palladium, the existence of which was hitherto hypothesized by Cavell [19]. Moreover, beside the clear evidence displayed by the NMR spectra<smiles></smiles><smiles></smiles>

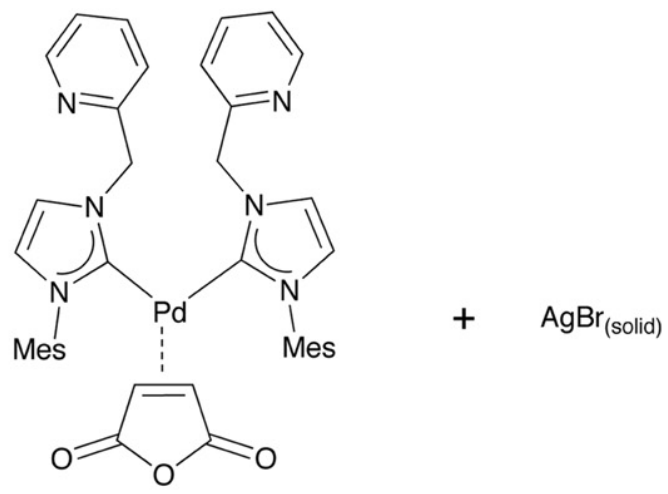



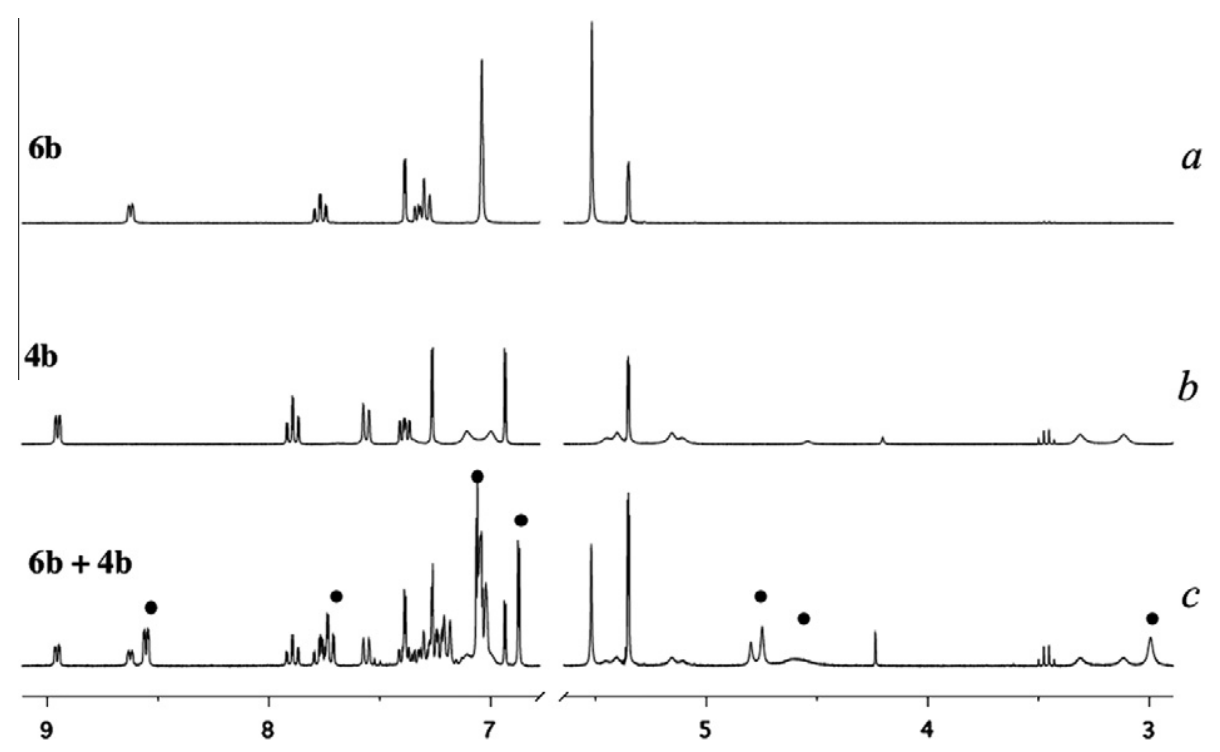

Fig. 1. Selected intervals of the ${ }^{1} \mathrm{H}$ NMR spectra at $298 \mathrm{~K}$ of $\mathrm{CD}_{2} \mathrm{Cl}_{2}$ solution of: (a) complex $\mathbf{6 b}$; [6b] $=1.5 \times 10^{-2} \mathrm{M}$; (b) complex $\mathbf{4 b}$; [4b] = $1.5 \times 10^{-2} \mathrm{M}$; (c) product $\mathbf{1 1}(\mathbf{0})$ from the equilibrium reaction between equimolecular amounts of complexes $\mathbf{4 b}$ and $\mathbf{6 b}$ (see Chart 2 and text).

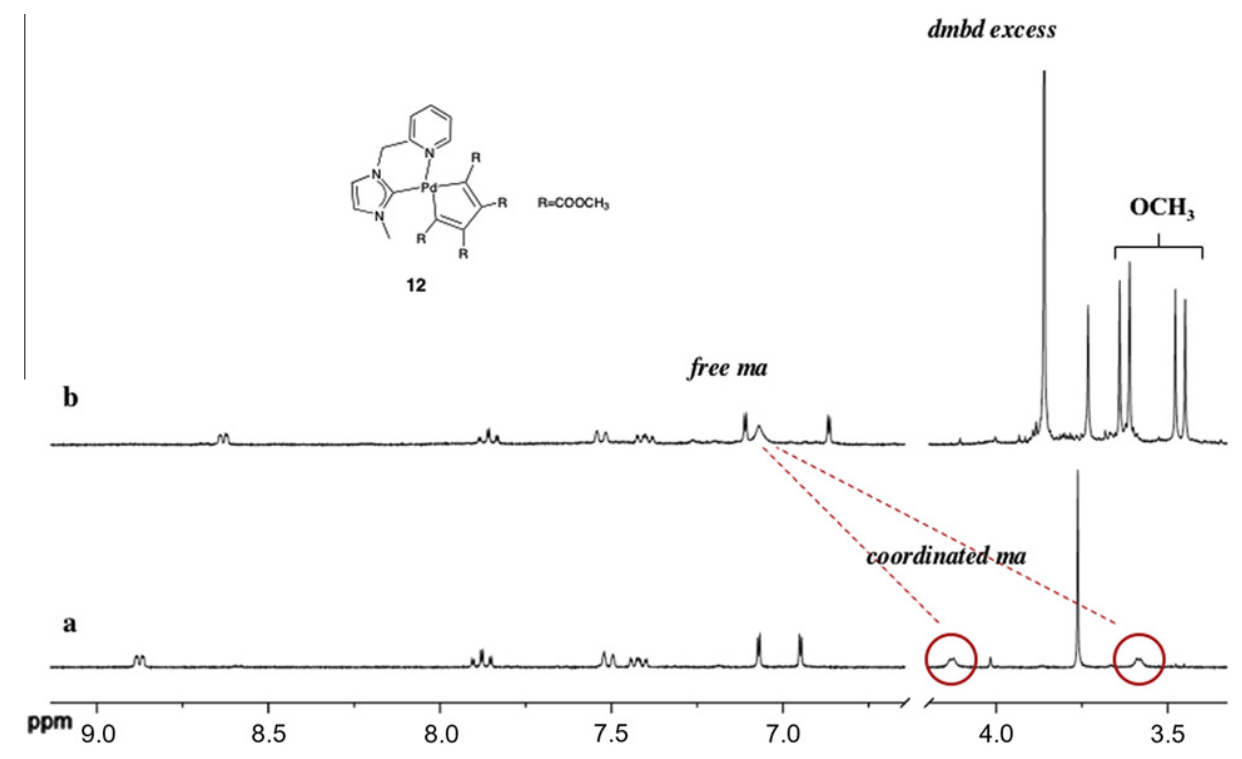

Fig. 2. Selected intervals of the ${ }^{1} \mathrm{H}$ NMR spectra at $298 \mathrm{~K}$ of $\mathrm{CD}_{2} \mathrm{Cl}_{2}$ solution of: (a) complex $\mathbf{6 a}$; [6a] $=1.5 \times 10^{-2} \mathrm{M}$; (b) complex 12; [12] = $1.5 \times 10^{-2} \mathrm{M}$. (top insert) topological representation of complex $\mathbf{1 2}$.

a theoretical investigation confirms the existence of a similar structure [20] (Chart 3b).

Remarkably, a palladium $(0)$ complex bearing one olefin and one alkyne coordinated was hypothesised as a possible intermediate in the case of the attack of an alkyne to an olefin derivative bearing a pyridylthioether as spectator ligand, but in that case its presence in solution was not detectable [21a]. The stability of such an intermediate might probably be traced back to the donor nature of carbene and consequently to the high electron density on the Pd center which can be consequently easily shared between the two electron withdrawing unsaturated molecules.

Increasing the temperature of the solution induces a general decomposition with formation of metallic palladium and several unidentified species.

Similar behavior is detectable in the case of complexes $\mathbf{5 a}$ and $\mathbf{6 b}$ whereas, as already stated, only the complex $\mathbf{6 a}$ yields the palladacyclopentadiene derivative [Pd( $\left.\left.\mathrm{Me}-\mathrm{NHC}-\mathrm{CH}_{2}-\mathrm{Py}\right)\left(\mathrm{C}_{4}(\mathrm{COOMe})_{4}\right)\right]$ upon increasing the temperature. Interestingly, the decomposition of complex 5a promotes the formation of the examethylmellitate derivative as can be deduced from the intense signal at $3.87 \mathrm{ppm}$ ascribable to its eighteen protons [21]. The progress of the reaction yielding the palladacyclometallate product is probably controlled by small differences in the steric and electronic demands among the investigated complexes and in our case only the complex $\mathbf{6 a}$ fulfills those steric requirements.

\subsection{Crystal structure determination}

ORTEP [22] views of complexes $\mathbf{5 b}$ and $\mathbf{9}$ are shown in Figs. $4 \mathrm{a}$ and $5 \mathrm{a}$. A selection of bond distances and angles is given in Table 1. In complex $\mathbf{5 b}$ the palladium is bonded to a dissymmetric NHC bidentate ligand through the carbene carbon and the sulfur atom of the methylthiophenyl N-substituent and $\eta^{2}$-coordinated to the $\mathrm{C}=\mathrm{C}$ double bond of maleic anhydride. In complex $\mathbf{9}$ the palladium is 
(a)<smiles></smiles>

$\mathrm{R}=\mathrm{COOMe}$

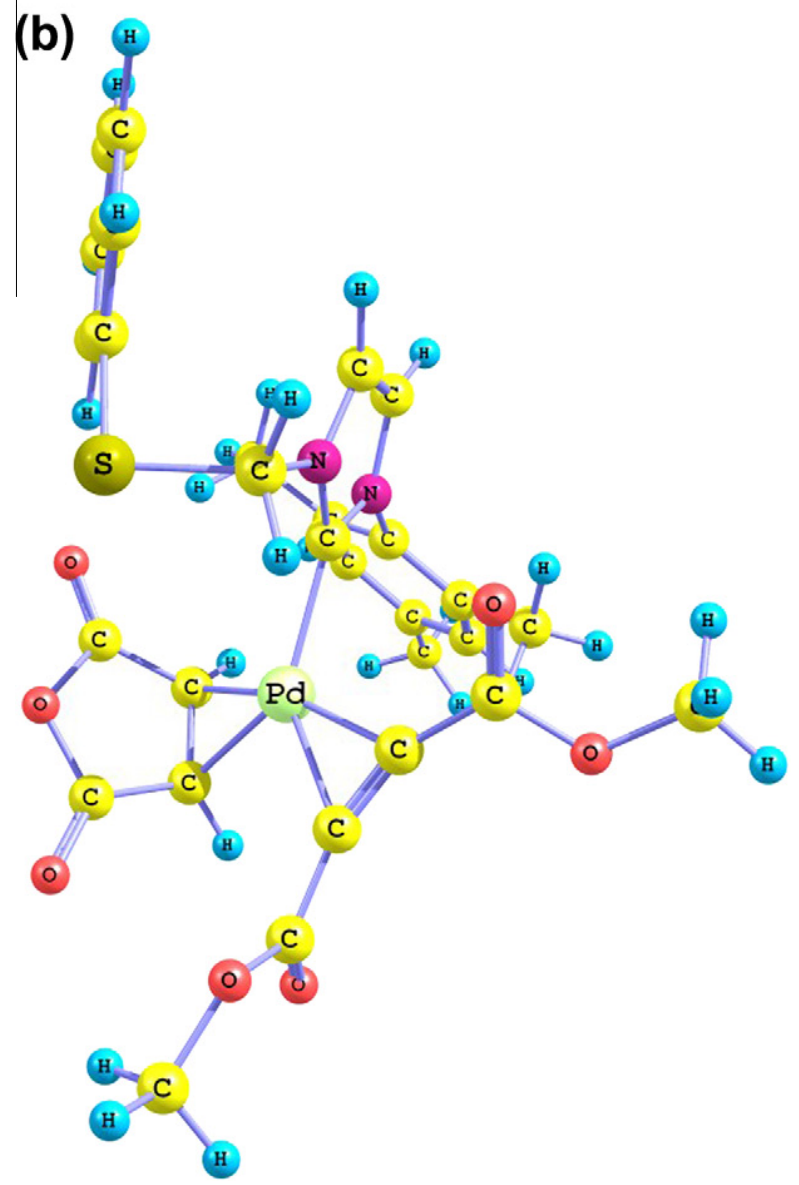

Chart 3. (a) Topological representation of the complex $\mathbf{1 3}$ bearing the monocoordinated ditopic carbene, the olefin ma and the alkyne dmbd coordinated and (b) structure of the complex $\mathbf{1 3}$ theoretically determined (see text).

bonded to two carbene carbons of two dissymmetric NHC ligands and $\eta^{2}$-coordinated to the $\mathrm{C}=\mathrm{C}$ double bond of maleic anhydride.

In both structures the palladium center is trigonal planar, as expected for zero-valent complexes of the type [PdL'L" ( $\eta^{2}$-alkene)]. All bond distances involving the $\operatorname{Pd}(0)$ metal are in reasonable agreement with those in other complexes of $\operatorname{Pd}(0)$ with maleic anhydride $[18,23]$. In complex $5 \mathbf{b}$ the Pd1-C2 length (2.125(3) $\AA$ ) is considerably longer than the corresponding Pd1-C1 (2.060(3) A) owing to the trans influence exerted by the carbene carbon of the ligand on the coordinated olefin, whereas the Pd-olefin distances in the case of complex $\mathbf{9}$ are similar in agreement with the findings of Lee et al. [18]. Remarkably, the Pd1-C5 and Pd1-C16 bonds in the bis-carbene derivative $\mathbf{9}$ are lengthened with respect to those of the Pd- $\mathrm{C}_{\text {carbene }}$ complex $\mathbf{5 b}$ and of those of the chelate heteroditopic complexes described elsewhere [5g,11c,13b] but compare well with those of the similar complexes described in Ref. [18]. This fact is probably due to the increased electronic charge on the metal center. The $\mathrm{C} 1=\mathrm{C} 2$ alkene bond lengths of $1.430(4)$ and $1.444(4) \AA$, for structures $\mathbf{5 b}$ and $\mathbf{9}$, respectively, are about $0.1 \AA$ longer than in the free alkene and are consistent with $\pi$-back bonding from $\operatorname{Pd}(0)$. The maleic anhydride rings are almost perpendicular to the basal coordination plane forming angles of $82.43(7)^{\circ}$ with the Pd1, C1, C2, C5, S1 mean coordination plane of complex $\mathbf{5 b}$ and of $79.5(8)^{\circ}$ with the Pd1, C1, C2, C5, C16 mean coordination plane of 9 (Figs. $4 \mathrm{~b}$ and $5 \mathrm{~b}$ ).

In the crystals the molecules are held together by means of C$\mathrm{H}$... O hydrogen bonds involving the oxygens of maleic anhydride as acceptors (Table 2).

\section{Conclusion}

We have synthesized new thioether derivatives of imidazolium salts 1a-1c, the corresponding silver bromide derivatives 3a-3c and the palladium $(0)$ complexes $\mathbf{5 a}-\mathbf{5 c}$. We have compared the chemical characteristics and reactivity of the latter with those of complexes $\mathbf{6 a}$ and $\mathbf{6 b}$ bearing the carbene-pyridine $\mathrm{R}-\mathrm{NHC}-\mathrm{CH}_{2}-$ Py fragments as spectator ligands and resolved the solid state structure of complex $\mathbf{5 b}$.

Taking advantage of the hemilability of the above mentioned ligands we were able to obtain complexes with two mono-coordinated heteroditopic ligands and maleic anhydride concomitantly bound to the metal (complexes 9-11) by adding one more equivalent of the silver carbenic precursor. From the NMR spectra of the reaction solutions it was clear that, despite the precipitation of $\mathrm{AgBr}$ an equilibrium mixture is often obtained in these cases. The structure of complex 9 bearing two different heteroditopic carbenes and an olefin concomitantly coordinated to a palladium $(0)$ center, was determined by means of a diffractometric study. Moreover, in the attempt to obtain palladacyclometallate derivatives bearing $\mathrm{R}-\mathrm{NHC}-\mathrm{CH}_{2}-\mathrm{SPh}$ or R-NHC- $\mathrm{CH}_{2}-\mathrm{Py}$ as ancillary ligands we have reacted complexes $\mathbf{5 a}, \mathbf{5 b}, \mathbf{6 a}$ and $\mathbf{6 b}$ with the alkyne dimethyl-2-butynedioate. The expected complex was obtained only in the case of $\mathbf{6 a}$, whereas complexes $\mathbf{5 a}, \mathbf{5 b}$ and $\mathbf{6 b}$ undergo massive decomposition at RT. In the latter cases, the formation of an intermediate bearing ma, dmbd and the monodentate heteroditopic carbene coordinated to the same metal center was shown by means of low temperature NMR spectra.

\section{Experimental}

\subsection{Materials}

All solvents were purified by standard procedures and distilled under argon immediately before use. 1D- and 2D-NMR spectra were recorded using a Bruker 300 Avance spectrometer. Chemical shifts (ppm) are given related to TMS $\left({ }^{1} \mathrm{H}\right.$ and ${ }^{13} \mathrm{C}$ NMR). IR spectra were recorded on a Perkin-Elmer Spectrum One spectrophotometer.

\subsection{Computational details}

Theoretical calculations were performed with the GAUSSIAN 09 [20] package using the functional hybrid meta-GGA M06 [20c] and the Def2-TZVP basis set [20b]. The geometry optimization was performed without any symmetry constraint, followed by analytical frequency calculation to confirm that a minimum had been reached. 


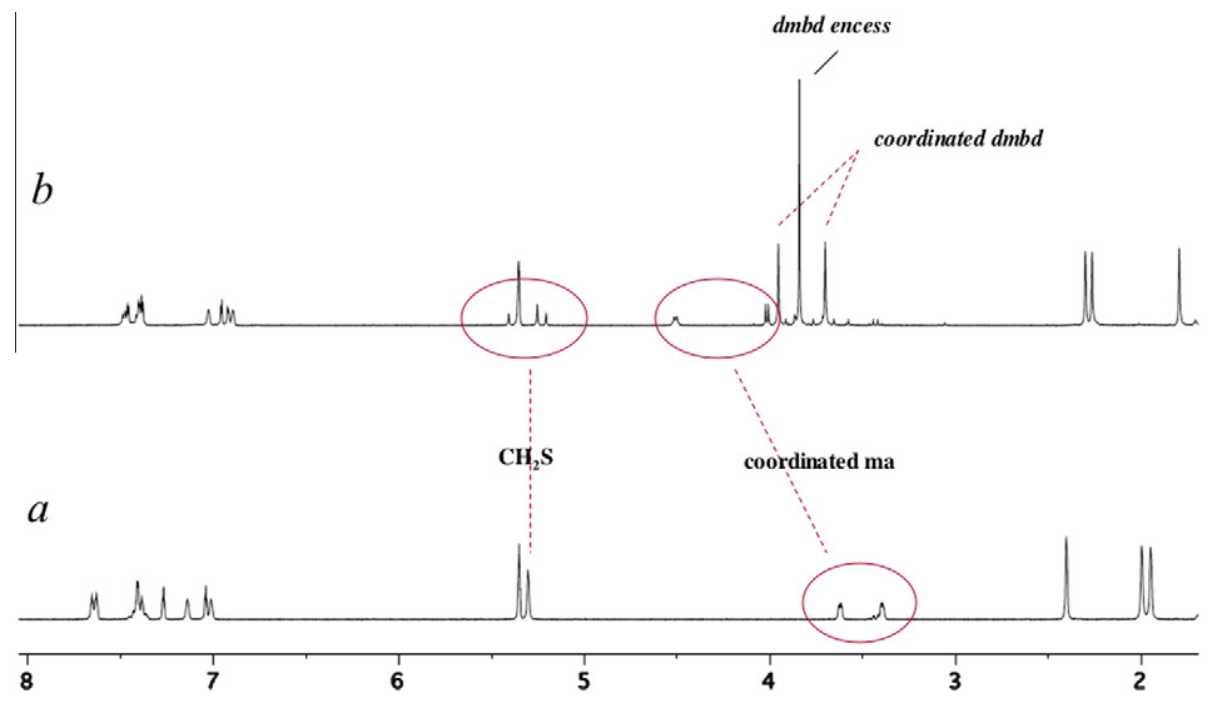

Fig. 3. Selected intervals of the ${ }^{1} \mathrm{H}$ NMR spectra at $298 \mathrm{~K}$ of a $\mathrm{CD}_{2} \mathrm{Cl}_{2}$ solution of: (a) complex $\mathbf{5 b}$; [5a] $=1.5 \times 10^{-2} \mathrm{M}$ and (b) compound $\mathbf{1 3}$.
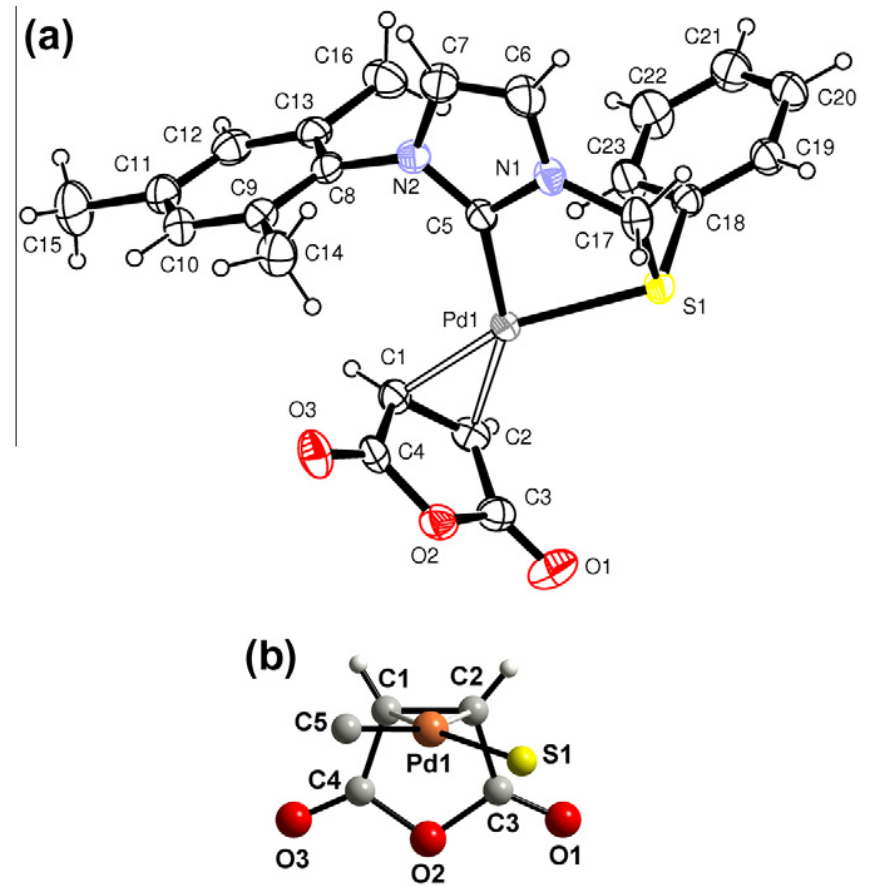

Fig. 4. (a) An ORTEP view of complex $\mathbf{5 b}$ showing the thermal ellipsoids at $30 \%$ probability level. (b) The orientation of $\eta^{2}$-maleic anhydride moiety with respect to the Pd coordination plane in complex $\mathbf{5 b}$.

\subsection{Crystal structure determinations}

The crystal data of compounds $\mathbf{5 b}$ and $\mathbf{9}$ were collected at room temperature using a Nonius Kappa CCD diffractometer with graphite monochromated Mo Ka radiation. The data sets were integrated with the Denzo-SMN package [24] and corrected for Lorentz, polarization and absorption effects (SORTAV). [25] The structures were solved by direct methods using sIR97 [26] system of programs and refined using full-matrix least-squares with all non-hydrogen atoms anisotropically and hydrogens included on calculated positions, riding on their carrier atoms.

All calculations were performed using SHELXL-97 [27] and PARST [28] implemented in WINGX [29] system of programs. The crystal data are given in Table 1 SI.
Table 1

Selected bond distances and angles ( $\AA$ and degrees).

\begin{tabular}{lll}
\hline & $\mathbf{5 b}$ & $\mathbf{9}$ \\
\hline Distances & & \\
Pd1-C5 & $2.040(3)$ & $2.067(3)$ \\
Pd1-S1 & $2.4157(8)$ & $2.061(2)$ \\
Pd1-C16 & & $2.101(3)$ \\
Pd1-C1 & $2.060(3)$ & $2.121(3)$ \\
Pd1-C2 & $2.125(3)$ & $1.444(4)$ \\
C1-C2 & $1.430(4)$ & $1.354(4)$ \\
C5-N1 & $1.359(3)$ & $1.357(4)$ \\
C5-N2 & $1.355(3)$ & $1.366(3)$ \\
C16-N3 & & $1.362(3)$ \\
C16-N4 & & \\
Angles & & $98.6(1)$ \\
C5-Pd1-S1 & & $108.1(1)$ \\
C5-Pd1-C16 & & \\
C5-Pd1-C1 & $82.5(1)$ & $147.9(1)$ \\
C5-Pd1-C2 & & \\
S1-Pd1-C1 & $116.2(1)$ & $152.8(1)$ \\
S1-Pd1-C2 & $155.5(1)$ & $113.4(1)$ \\
C16-Pd1-C1 & $161.1(1)$ & $40.0(1)$ \\
C16-Pd1-C2 & $121.7(1)$ & \\
C1-Pd1-C2 & & \\
Dihedral Angles & & \\
Pd1,C1,C2,C5,S1 & $39.9(1)$ & \\
C1,C2,C3,C4,O2 & & \\
Pd1,C1,C2,C5,C16^ & & \\
C1,C2,C3,C4,O2 & & \\
\hline
\end{tabular}

Crystallographic data (excluding structure factors) have been deposited at the Cambridge Crystallographic Data center and allocated the deposition numbers CCDC 848987 and CCDC 848988. These data can be obtained free of charge via www.ccdc.cam.ac.uk/conts/retrieving.html or on application to CCDC, Union Road, Cambridge, CB2 1EZ, UK (fax: +44 1223-336033, e-mail: deposit@ccdc.cam.ac.uk).

\subsection{Synthesis of the precursors}

The palladium precursors $\mathrm{Pd}_{2}(\mathrm{DBA})_{3} \cdot \mathrm{CH}_{3} \mathrm{Cl}$, [30] $\left[\mathrm{Pd}\left(\eta^{2}-\mathrm{ma}\right)-\right.$ COD], [31] [(2-methyl-6-(phenylthiomethyl)pyridine)palladium(0) (naphthoquinone)] [23a] and [(2-methyl-6-(phenylthiomethyl) 
Table 2

Hydrogen bond parameters ( $\AA$ and degrees).

\begin{tabular}{|c|c|c|c|c|c|}
\hline $\mathrm{A}-\mathrm{H} \cdots \mathrm{B}$ & $\mathrm{A}-\mathrm{H}$ & A $\cdots B$ & Symm. Op. & $\mathrm{H} \cdots \mathrm{B}$ & $\mathrm{A}-\mathrm{H} \cdots \mathrm{B}$ \\
\hline \multicolumn{6}{|l|}{$5 b$} \\
\hline $\mathrm{C} 6-\mathrm{H} 6 \cdots \mathrm{O} 3$ & 0.93 & $3.167(4)$ & $\begin{array}{l}3 / 2-x, y-1 / 2 \\
z-1 / 2\end{array}$ & 2.24 & 172 \\
\hline $\mathrm{C} 16-\mathrm{H} 16 \mathrm{~A} \cdots \mathrm{O} 1$ & 0.96 & $3.449(5)$ & $x-1 / 2,3 / 2-y, z$ & 2.58 & 151 \\
\hline $\mathrm{C} 22-\mathrm{H} 22 \ldots \mathrm{O} 2$ & 0.93 & $3.409(4)$ & $x, y-1 . z$ & 2.52 & 159 \\
\hline $\mathrm{C} 19-\mathrm{H} 19 \ldots \mathrm{O} 2$ & 0.93 & $3.527(3)$ & $\begin{array}{l}2-x, 2-y \\
z-1 / 2\end{array}$ & 2.65 & 158 \\
\hline \multicolumn{6}{|l|}{9} \\
\hline $\mathrm{C} 31-\mathrm{H} 31 \ldots \mathrm{O} 3$ & 0.93 & $3.364(5)$ & $\begin{array}{l}1 / 2+x, 1 / 2-y \\
z-1 / 2\end{array}$ & 2.48 & 159 \\
\hline $\mathrm{C} 17-\mathrm{H} 17 \ldots \mathrm{O} 3$ & 0.93 & $3.258(3)$ & $\begin{array}{l}1 / 2-x, y- \\
1 / 2,1 / 2-z\end{array}$ & 2.40 & 153 \\
\hline $\mathrm{C} 28-\mathrm{H} 28 \mathrm{~B} \cdots \mathrm{O} 1$ & 0.97 & $3.439(3)$ & $-x,-y,-z$ & 2.55 & 152 \\
\hline
\end{tabular}

(a)
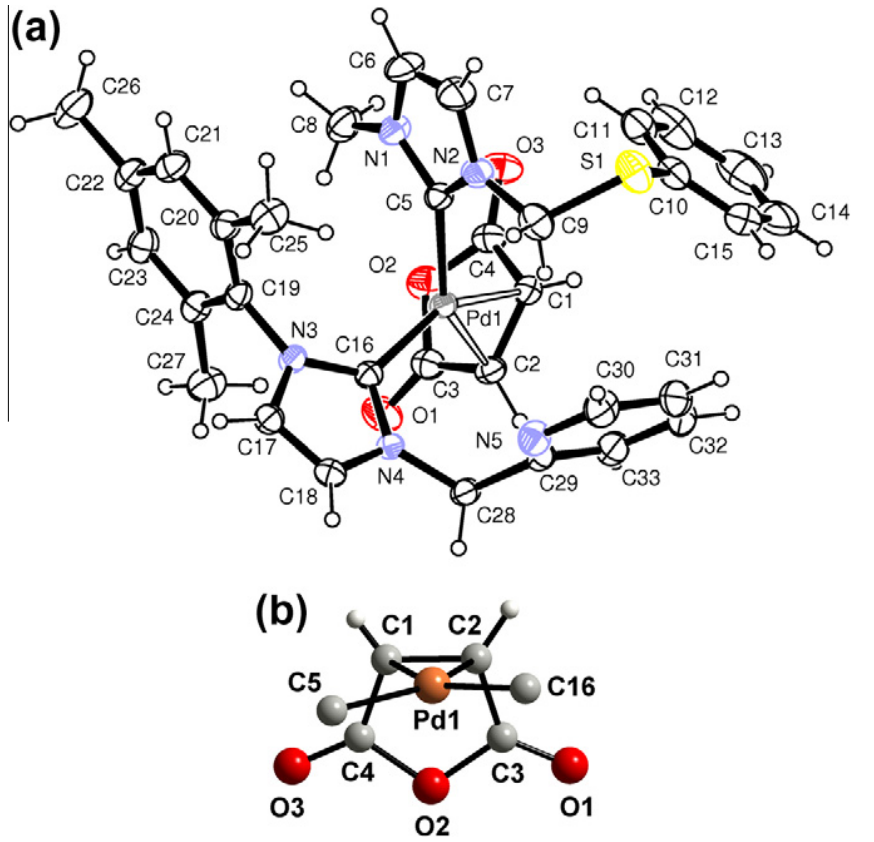

Fig. 5. (a) An ORTEP view of complex 9 showing the thermal ellipsoids at $30 \%$ probability level. (b) The orientation of $\eta^{2}$-maleic anhydride moiety with respect to the Pd coordination plane in complex $\mathbf{9}$

pyridine)palladium(0)(tetramethyl ethene tetracarboxylate)] [23e] were synthesized according to published procedures.

\subsection{Synthesis of the N-arylimidazoles}

The syntheses of the $\mathrm{N}$-mesityl-imidazole and $\mathrm{N}$-2,6-diisopropylphenyl-imidazole were carried out according to the optimized published procedure. [9] The nucleophilic attack of the appropriate arylamine to oxalaldehyde in $\mathrm{MeOH}$ at RT was followed by the cyclization reaction of the cheto-imino derivatives in the presence of ammonium chloride, formaldehyde and phosphoric acid. The reaction products were extracted in diethylether and re-crystallized. The $\mathrm{N}$-methyl-imidazole was a commercial product and used as purchased.

\subsection{Synthesis of the N-arylimidazolium salts}

[1-(2-Pyridyl)methylene-3-mesityl]imidazolium bromide (2b), [1-(2-pyridyl)methylene-3-(2,6-di-i-propylphenyl)]imidazolium bromide (2c) \{[1-(2-pyridyl)methylene-3-mesetyl]imidazolyl-2- ene $\}$ silver bromide (4b) \{[1-(2-pyridyl)methylene-3-(2,6-diisopro pylphenyl)]imidazolyl-2-ene\}silver bromide (4c) were prepared following literature procedures [11c].

\section{7. [1-(Phenylthio)methylene-3-methyl]imidazolium bromide (1a)}

To a solution of $0.93 \mathrm{~g}(13.8 \mathrm{mmol})$ of $\mathrm{N}$-methyl-imidazole in anhydrous $\mathrm{MeCN}(40 \mathrm{ml}), 2 \mathrm{~g}(12.6 \mathrm{mmol})$ of chloro-methyl-phenyl-sulfide and $1.65 \mathrm{~g}(13.9 \mathrm{mmol})$ of $\mathrm{KBr}$ were added under inert atmosphere $(\mathrm{Ar})$.The resulting suspension was stirred for $48 \mathrm{~h}$, treated with $60 \mathrm{ml}$ of $\mathrm{CH}_{2} \mathrm{Cl}_{2}$ and filtered on a Celite filter. The clear solution was dried under vacuum and the residue was re-dissolved in $\mathrm{CH}_{2} \mathrm{Cl}_{2}(2-3 \mathrm{ml})$ and re-precipitated with diethylether as a sticky white solid. $2.68 \mathrm{~g}$ (yield $94 \%$ ) of the title dry product were obtained upon decantation and evaporation of the solvent.

${ }^{1} \mathrm{H}$ NMR $\left(\mathrm{CDCl}_{3}, T=298 \mathrm{~K}, \mathrm{ppm}\right) \delta: 3.99\left(\mathrm{~s}, 3 \mathrm{H}, \mathrm{NCH}_{3}\right), 6.28(\mathrm{~s}$, $\left.2 \mathrm{H}, \mathrm{SCH}_{2}\right), 5.86(\mathrm{~s}, 2 \mathrm{H}, \mathrm{m}$-mesityl), $7.33(\mathrm{~m}, 3 \mathrm{H}, \mathrm{SPh}), 7.40(\mathrm{t}$, $J=1.8 \mathrm{~Hz}, 1 \mathrm{H}, \mathrm{CH}=\mathrm{CH} \mathrm{Im}), 7.44(\mathrm{~m}, 2 \mathrm{H}, \mathrm{SPh}), 7.51(\mathrm{t}, J=1.7 \mathrm{~Hz}$, $1 \mathrm{H}, \mathrm{CH}=\mathrm{CH} \mathrm{Im}), 9.99$ (bs, $1 \mathrm{H}, \mathrm{NCHN}) .{ }^{13} \mathrm{C}\left\{{ }^{1} \mathrm{H}\right\}$ NMR $\left(\mathrm{CDCl}_{3}\right.$, $T=298 \mathrm{~K}, \mathrm{ppm}) \delta: 36.8\left(\mathrm{CH}_{3}, \mathrm{NCH}_{3}\right), 53.4\left(\mathrm{CH}_{2}, \mathrm{SCH}_{2}\right), 121.7(\mathrm{CH}$, $\mathrm{CH}=\mathrm{CH} \operatorname{Im}), 123.8(\mathrm{CH}, \mathrm{CH}=\mathrm{CH} \mathrm{Im}), 128.8(\mathrm{CH}, \mathrm{SPh}-\mathrm{CH}), 129.7$ (CH, SPh-CH), 130.4 (C, SPh-C), $132.2(\mathrm{CH}, \mathrm{CPh}-\mathrm{CH}), 136.5(\mathrm{CH}$, NCHN). Anal. Calc. for $\mathrm{C}_{11} \mathrm{H}_{13} \mathrm{BrN}_{2} \mathrm{~S}$ : C, 46.32; H, 4.59; N, 9.82. Found: C, $46.21 ; \mathrm{H}, 4.62 ; \mathrm{N}, 9.90 \%$.

The following derivatives were prepared in a similar way using the appropriate reactants.

\section{8. [1-(Phenylthio)methylene-3-mesityl]imidazolium bromide (1b)}

White micro crystals: Yield $77 \% .{ }^{1} \mathrm{H}$ NMR $\left(\mathrm{CDCl}_{3}, T=298 \mathrm{~K}\right.$, ppm) $\delta: 1.87\left(\mathrm{~s}, 6 \mathrm{H}, o\right.$-mesityl- $\left.\mathrm{CH}_{3}\right), 2,33\left(\mathrm{~s}, 3 \mathrm{H}, p\right.$-mesityl- $\left.\mathrm{CH}_{3}\right)$, $6.28\left(\mathrm{~s}, 2 \mathrm{H}, \mathrm{SCH}_{2}\right), 6.95(\mathrm{~s}, 2 \mathrm{H}, m$-mesityl-H), $7.04(\mathrm{t}, J=1.8 \mathrm{~Hz}$, $1 \mathrm{H}, \mathrm{CH}=\mathrm{CH} \mathrm{Im}), 7.35(\mathrm{~m}, 3 \mathrm{H}, \mathrm{SPh}), 7.62(\mathrm{~m}, 2 \mathrm{H}, \mathrm{SPh}), 7.69(\mathrm{t}$, $J=1.7 \mathrm{~Hz}, 1 \mathrm{H}, \mathrm{CH}=\mathrm{CH} \mathrm{Im}$ ), 10.22 (bs, $1 \mathrm{H}, \mathrm{NCHN}$ ).

${ }^{13} \mathrm{C}\left\{{ }^{1} \mathrm{H}\right\}$ NMR $\left(\mathrm{CDCl}_{3}, T=298 \mathrm{~K}, \mathrm{ppm}\right) \delta: 17.3\left(\mathrm{CH}_{3}\right.$, o-mesityl$\left.\mathrm{CH}_{3}\right), 20.9\left(\mathrm{CH}_{3}, p\right.$-mesityl- $\left.\mathrm{CH}_{3}\right), 53.4\left(\mathrm{CH}_{2}, \mathrm{SCH}_{2}\right), 121.7(\mathrm{CH}$, $\mathrm{CH}=\mathrm{CH} \mathrm{Im}), 122.8(\mathrm{CH}, \mathrm{CH}=\mathrm{CH} \mathrm{Im}), 129.0(\mathrm{CH}, \mathrm{SPh}-\mathrm{CH}), 129.5$ (C, SPh-C), 129.6 (CH, SPh-CH), 129.7 (CH, m-mesityl-CH), 130.2 (C, o-mesityl-C), 132.7 (CH, SPh-CH), 134.0 (C, SPh-C), 138.4 (CH, NCHN), 141.4 (C, p-mesityl-C). Anal. Calc. for $\mathrm{C}_{19} \mathrm{H}_{21} \mathrm{BrN}_{2} \mathrm{~S}$ : C, 58.61; H, 5.44; N, 7.19. Found: C, 58.59; H, 5.47; N, 7.12\%.

\section{9. [1-(Phenylthio)methyl-3-(2,6-di-i-propylphenyl)]imidazolium bromide (1c)}

White micro crystals: Yield $68 \% .{ }^{1} \mathrm{HNMR}\left(\mathrm{CD}_{2} \mathrm{Cl}_{2}, T=298 \mathrm{~K}\right.$, ppm) $\delta: 1.06\left(\mathrm{~d}, J=6.8 \mathrm{~Hz}, 6 \mathrm{H}, i \mathrm{Pr}-\mathrm{CH}_{3}\right), 1.13(\mathrm{~d}, J=6.8 \mathrm{~Hz}, 6 \mathrm{H}$, $\left.i \mathrm{Pr}-\mathrm{CH}_{3}\right), 2.01$ (sept, $\left.J=6.8 \mathrm{~Hz}, 2 \mathrm{H}, i \mathrm{Pr}-\mathrm{CH}\right), 6.42\left(\mathrm{~s}, 2 \mathrm{H}, \mathrm{SCH}_{2}\right.$ ), $7.07(\mathrm{~d}, J=1.8 \mathrm{~Hz}, 1 \mathrm{H}, \mathrm{CH}=\mathrm{CH} \mathrm{Im}), 7.26(\mathrm{~d}, J=7.9 \mathrm{~Hz}, 2 \mathrm{H}, m$-aryl$\mathrm{H}), 7.30-7.40(\mathrm{~m}, 3 \mathrm{H}, \mathrm{SPh}), 7.50(\mathrm{t}, J=7.9 \mathrm{~Hz}, 2 \mathrm{H}, p$-aryl-H), 7.65$7.68(\mathrm{~m}, 2 \mathrm{H}, \mathrm{SPh}), 7.89(\mathrm{~d}, J=1.8 \mathrm{~Hz}, 1 \mathrm{H}, \mathrm{CH}=\mathrm{CH} \mathrm{Im}), 10.37(\mathrm{bm}$, $1 \mathrm{H}, \mathrm{NCHN}) .{ }^{13} \mathrm{C}\left\{{ }^{1} \mathrm{H}\right\} \mathrm{NMR}\left(\mathrm{CD}_{2} \mathrm{Cl}_{2}, T=298 \mathrm{~K}, \mathrm{ppm}\right) \delta: 23.8\left(\mathrm{CH}_{3}\right.$, $\left.i \mathrm{Pr}-\mathrm{CH}_{3}\right), 22.9\left(\mathrm{CH}_{3}, i \mathrm{Pr}-\mathrm{CH}_{3}\right), 28.4(\mathrm{CH}, i \mathrm{Pr}-\mathrm{CH}), 53.6\left(\mathrm{CH}_{2}, \mathrm{SCH}_{2}\right)$, $122.0(\mathrm{CH}, \mathrm{CH}=\mathrm{CH} \mathrm{Im}), 124.2(\mathrm{CH}, \mathrm{CH}=\mathrm{CH} \mathrm{Im}), 124.5(\mathrm{CH}, m-$ aryl-CH), $128.8(\mathrm{CH}, \mathrm{SPh}-\mathrm{CH}), 129.6(\mathrm{CH}, \mathrm{SPh}-\mathrm{CH}), 129.7(\mathrm{C}, i-$ aryl-C), 129.8 (C, SPh-C), $131.7(\mathrm{CH}, p$-aryl-CH), $132.3(\mathrm{CH}, \mathrm{SPh}-$ $\mathrm{CH}), 138.2(\mathrm{CH}, \mathrm{NCHN}), 128.7$ (C, o-aryl-C). Anal. Calc. for $\mathrm{C}_{22} \mathrm{H}_{27} \mathrm{BrN}_{2} \mathrm{~S}: \mathrm{C}, 61.25 ; \mathrm{H}, 6.31 ; \mathrm{N}, 6.49$. Found: C, 61.31; H, 6.28; $\mathrm{N}, 6.53 \%$.

\subsection{0. [1-(2-Pyridyl)methylene-3-methyl]imidazolium bromide (2a)}

To an anhydrous MeCN solution (70 ml) of $3 \mathrm{~g}(23.5 \mathrm{mmol})$ of 2chloromethylpyridine (obtained by neutralization with $\mathrm{Na}_{2} \mathrm{CO}_{3}$ of the corresponding hydrochloride), $4.13 \mathrm{~g}(34.5 \mathrm{mmol})$ of $\mathrm{KBr}$ and $2.1 \mathrm{ml}$ ( $25.5 \mathrm{mmol})$ of $\mathrm{N}$-methylimidazole were added under inert 
atmosphere ( $\mathrm{Ar}$ ). The red-orange mixture was stirred for $48 \mathrm{~h}$ and the solvent reduced to 3-4 ml under vacuum. An equivalent volume of $\mathrm{CH}_{2} \mathrm{Cl}_{2}(70 \mathrm{ml})$ was then added and the resulting suspension was filtered on a Celite filter. The clear solution was evaporated to dryness and the reddish sticky residue was re-dissolved in $\mathrm{CH}_{2} \mathrm{Cl}_{2}$ $(15 \mathrm{ml})$ and precipitated with diethylether $(40 \mathrm{ml}) .5 .08 \mathrm{~g}$ (yield $87 \%$ ) of red hygroscopic micro crystals were obtained.

${ }^{1} \mathrm{H} \mathrm{NMR}\left(\mathrm{CDCl}_{3}, T=298 \mathrm{~K}, \mathrm{ppm}\right) \delta: 4.06\left(\mathrm{~s}, 3 \mathrm{H}, \mathrm{NCH}_{3}\right) 5.76(\mathrm{~s}, 2 \mathrm{H}$, $\left.\mathrm{NCH}_{2}\right), 7.27(\mathrm{~d}, J=1,6 \mathrm{~Hz}, 1 \mathrm{H}, \mathrm{CH}=\mathrm{CH} \mathrm{Im}), 7.30(\mathrm{~m}, 1 \mathrm{H}, 5-\mathrm{Pyr}), 7.63$ (d, $J=1,6 \mathrm{~Hz}, 1 \mathrm{H}, \mathrm{CH}=\mathrm{CH} \mathrm{Im}$ ), 7.77 (td, $J=7.4,1.6 \mathrm{~Hz}, 1 \mathrm{H}, 4-\mathrm{Pyr}$ ), 7.84 (d, $J=7.4 \mathrm{~Hz}, 1 \mathrm{H}, 3-\mathrm{Pyr}$ ), 8.55 (d, $J=4.9 \mathrm{~Hz}, 1 \mathrm{H}, 6 \mathrm{Pyr}$ ), 10.71 (bs, $1 \mathrm{H}, \mathrm{NCHN}) .{ }^{13} \mathrm{C}\left\{{ }^{1} \mathrm{H}\right\}$ NMR $\left(\mathrm{CDCl}_{3}, T=298 \mathrm{~K}, \mathrm{ppm}\right) \delta: 36.6$ $\left(\mathrm{CH}_{3}, \mathrm{NCH}_{3}\right), 53.7\left(\mathrm{CH}_{2}, \mathrm{NCH}_{2}\right), 122.7(\mathrm{CH}, 5-\mathrm{Py}), 123.3(\mathrm{CH}, \mathrm{CH}=\mathrm{CH}$ Im), $123.6(\mathrm{CH}, \mathrm{CH}=\mathrm{CH} \mathrm{Im}), 123.8(\mathrm{CH}, 3-\mathrm{Py}), 137.3(\mathrm{CH}, 4-\mathrm{Py})$, 137.5 (CH, NHC), 149.7 (CH, 6-Py), 152.3 (C, 2-Py). Anal. Calc. for $\mathrm{C}_{10} \mathrm{H}_{12} \mathrm{BrN}_{3}$ : C, 47.26; $\mathrm{H}, 4.76 ; \mathrm{N}, 16.54$. Found: $\mathrm{C}, 47.19 ; \mathrm{H}, 4.73$; $\mathrm{N}, 16.59 \%$.

\subsection{1. $\{[1$-(Phenylthio)methylene-3-methyl]imidazolyl-2-ene\} silver bromide (3a)}

To a solution of $0.322 \mathrm{~g}(1.13 \mathrm{mmol})$ of [Me- $\left.\mathrm{NHC}-\mathrm{CH}_{2}-\mathrm{SPh}\right] \mathrm{Br}$ in anhydrous $\mathrm{CH}_{2} \mathrm{Cl}_{2}(20 \mathrm{ml})$ under inert atmosphere $(\mathrm{Ar}) 0.144 \mathrm{~g}$ ( $0.621 \mathrm{mmol}$ ) of $\mathrm{Ag}_{2} \mathrm{O}$ was added. The mixture was stirred in the dark for $12 \mathrm{~h}$ and filtered on a Celite filter. The clear solution was evaporated to small volume under vacuum and the title product was precipitated by addition of diethylether filtered on gouch and washed with diethylether and pentane. $0.378 \mathrm{~g}$ (yield 85\%) of the complex as a whitish solid was obtained. ${ }^{1} \mathrm{H}$ NMR $\left(\mathrm{CD}_{2} \mathrm{Cl}_{2}\right.$, $T=298 \mathrm{~K}, \mathrm{ppm}) \delta: 3.76\left(\mathrm{~s}, 3 \mathrm{H}, \mathrm{NCH}_{3}\right), 5.42\left(\mathrm{~s}, 2 \mathrm{H}, \mathrm{SCH}_{2}\right), 7.00(\mathrm{~d}$, $J=1.8 \mathrm{~Hz}, 1 \mathrm{H}, \mathrm{CH}=\mathrm{CH} \mathrm{Im}), 7.11(\mathrm{~d}, J=1.8 \mathrm{~Hz}, 1 \mathrm{H}, \mathrm{CH}=\mathrm{CH} \mathrm{Im})$, $7.38(\mathrm{~m}, 5 \mathrm{H}, \mathrm{SPh}) .{ }^{13} \mathrm{C}\left\{{ }^{1} \mathrm{H}\right\}$ NMR $\left(\mathrm{CDCl}_{3}, T=253 \mathrm{~K}, \mathrm{ppm}\right) \delta: 38.7$ $\left(\mathrm{CH}_{3}, \mathrm{NCH}_{3}\right) .56 .2\left(\mathrm{CH}_{2}, \mathrm{SCH}_{2}\right), 120.4(\mathrm{CH}, \mathrm{CH}=\mathrm{CH} \mathrm{Im}), 122.6(\mathrm{CH}$, $\mathrm{CH}=\mathrm{CH} \mathrm{Im}), 129.7(\mathrm{CH}, \mathrm{SPh}-\mathrm{CH}), 129.0(\mathrm{CH}, \mathrm{SPh}-\mathrm{CH}), 130.9(\mathrm{C}$, $\mathrm{SPh}-\mathrm{C}), 133.3(\mathrm{CH}, \mathrm{SPh}-\mathrm{CH}), 182.2(\mathrm{C}, \mathrm{NCN})$. Anal. Calc. for $\mathrm{C}_{11} \mathrm{H}_{12} \mathrm{AgBrN}_{2} \mathrm{~S}$ : C, 33.70; H, 3.09; N, 7.15. Found: C, 33.73; $\mathrm{H}$, $2.99 ; \mathrm{N}, 7.21 \%$.

The following derivatives were prepared in a similar way using the appropriate reactants.

\subsection{2. $\{[1$-(Phenylthio)methylene-3-mesityl]imidazolyl-2-ene $\}$ silver bromide (3b)}

Light brown microcrystals: Yield $83 \%{ }^{1}{ }^{\mathrm{H}} \mathrm{NMR}\left(\mathrm{CDCl}_{3}, \mathrm{~T}=298 \mathrm{~K}\right.$, ppm) $\delta: 1.80\left(\mathrm{~s}, 6 \mathrm{H}, o\right.$-mesityl $\left.\mathrm{CH}_{3}\right), 2.31\left(\mathrm{~s}, 3 \mathrm{H}, p\right.$-mesityl $\left.\mathrm{CH}_{3}\right)$, $5.51\left(\mathrm{~s}, 2 \mathrm{H}, \mathrm{SCH}_{2}\right), 6.91(\mathrm{~m}, 3 \mathrm{H}, \mathrm{CH}=\mathrm{CH} \mathrm{Im}, m$-mesityl-H), 7.34 $(\mathrm{m}, 3 \mathrm{H}, \mathrm{SPh}), 7.37(\mathrm{~d}, J=1.8 \mathrm{~Hz}, 1 \mathrm{H}, \mathrm{CH}=\mathrm{CH} \mathrm{Im}), 7.45(\mathrm{~m}, 2 \mathrm{H}$, $\mathrm{SPh}),{ }^{13} \mathrm{C}\left\{{ }^{1} \mathrm{H}\right\}$ NMR $\left(\mathrm{CDCl}_{3}, T=298 \mathrm{~K}, \mathrm{ppm}\right) \delta: 17.5\left(\mathrm{CH}_{3}, o\right.$-mesityl- $\left.\mathrm{CH}_{3}\right), 20.9\left(\mathrm{CH}_{3}, p\right.$-mesityl- $\left.\mathrm{CH}_{3}\right), 56.4\left(\mathrm{CH}_{2}, \mathrm{SCH}_{2}\right), 120.2(\mathrm{CH}$, $\mathrm{CH}=\mathrm{CH} \mathrm{Im}), 123.4(\mathrm{CH}, \mathrm{CH}=\mathrm{CH} \mathrm{Im}), 129.2(\mathrm{CH}, m$-mesityl- $\mathrm{CH})$, 129.3 (C, o-mesityl-C), 129.8 (CH, SPh-CH), 130.01 (C, SPh-C), 133.8 (CH, SPh-CH), 134.4 ( CH, SPh-CH), 134.9 (C, $i$-mesityl-C), 139.5 (C, p-mesityl-C), 183.1 (C, NCN). Anal. Calc. for $\mathrm{C}_{19} \mathrm{H}_{20} \mathrm{AgBrN}_{2} \mathrm{~S}$ : C, 45.99; H, 4.06; N, 5.65. Found: C, 46.03; H, $4.11 ; \mathrm{N}, 5.67 \%$.

\subsection{3. \{[1-(Phenylthio)methylene-3-(2,6-di-i- propylphenyl)]imidazolyl-2-ene\}silver bromide (3c)}

White microcrystals: Yield 92\%. ${ }^{1} \mathrm{H}$ NMR $\left(300 \mathrm{MHz}, \mathrm{CDCl}_{3}\right) \delta$ : 1.06 (d, $J=6.9 \mathrm{~Hz}, 6 \mathrm{H}, \mathrm{iPr}-\mathrm{CH} 3$ ), 1.11 (t, $J=6.8 \mathrm{~Hz}, 6 \mathrm{H}, \mathrm{iPr}-\mathrm{CH} 3$ ), 2.12 (sept, $J=6.8 \mathrm{~Hz}, 2 \mathrm{H}, \mathrm{iPr}-\mathrm{CH}$ ), $5.54\left(\mathrm{~s}, 2 \mathrm{H}, \mathrm{CH}_{2}-\mathrm{S}\right.$ ), 6.95 (s, $1 \mathrm{H}$, $\mathrm{CH}=\mathrm{CH} \mathrm{Im}), 7.19(\mathrm{~d}, J=7.8 \mathrm{~Hz}, 2 \mathrm{H}, \mathrm{CH} o-\mathrm{Ph}), 7.33-7.38(\mathrm{~m}, 3 \mathrm{H}$, CH mesityl), 7.39-7.43 (m, $2 \mathrm{H}, \mathrm{CH}=\mathrm{CH}$ Im, $\mathrm{CH} p-\mathrm{Ph}), 7.44-7.50$ $(\mathrm{m}, 2 \mathrm{H}, \mathrm{CH} m-\mathrm{Ph}) .13 \mathrm{C}$ NMR $\left(75 \mathrm{MHz}, \mathrm{CDCl}_{3}\right) \delta: 24.2\left(\mathrm{CH}_{3}, i \mathrm{Pr}-\right.$ $\left.\mathrm{CH}_{3}\right), 24.3\left(\mathrm{CH}_{3}, i \mathrm{Pr}-\mathrm{CH}_{3}\right), 28.0(\mathrm{CH}, i \mathrm{Pr}-\mathrm{CH}), 56.3\left(\mathrm{CH}_{2}, \mathrm{CH}_{2}-\mathrm{S}\right)$,
$119.9(\mathrm{CH}, \mathrm{CH}=\mathrm{CH} \mathrm{Im}), 124.1(\mathrm{CH}$ o-Ph $), 124.7(\mathrm{CH}, \mathrm{CH}=\mathrm{CH} \mathrm{Im})$, 129.2 (CH, $p$-DiPP), 129.8 (CH, $m$-Ph), 130.5 (CH, $p$-Ph), 133.5 (C, i-DiPP), 145.4 (C, o-DiPP-C), 183.6 (C, NHC). Anal. Calc. for $\mathrm{C}_{22} \mathrm{H}_{26} \mathrm{AgBrN}_{2} \mathrm{~S}: \mathrm{C}, 49.09 ; \mathrm{H}, 4.87 ; \mathrm{N}, 5.20$. Found: $\mathrm{C}, 49.18 ; \mathrm{H}$, $4.75 ; \mathrm{N}, 5.29 \%$.

\subsection{4. $\{[1-(2-P y r i d y l) m e t h y l e n e-3-m e t h y l] i m i d a z o l y l-2-e n e\}$ silver bromide (4a)}

White microcrystals: Yield $71 \% .{ }^{1} \mathrm{H}$ NMR $\left(\mathrm{CDCl}_{3}, T=298 \mathrm{~K}, \mathrm{ppm}\right)$ $\delta: 3.87\left(\mathrm{~d}, J=0.7 \mathrm{~Hz}, 3 \mathrm{H}, \mathrm{NCH}_{3}\right), 5.44\left(\mathrm{~s}, 2 \mathrm{H}, \mathrm{NCH}_{2}\right), 7.00(\mathrm{~d}$, $J=1.8 \mathrm{~Hz}, 1 \mathrm{H}, \mathrm{CH}=\mathrm{CH} \mathrm{Im}), 7.18(\mathrm{~d}, J=1.8 \mathrm{~Hz}, 1 \mathrm{H}, \mathrm{CH}=\mathrm{CH} \mathrm{Im})$, 7.24 (dd, $J=7.6,4.9 \mathrm{~Hz}, 1 \mathrm{H}, 5-\mathrm{Pyr}$ ), 7.39 (d, $J=7.6 \mathrm{~Hz}, 1 \mathrm{H}, 3-\mathrm{Pyr}$ ), 7.69 (td, $J=7.6,1.6 \mathrm{~Hz}, 1 \mathrm{H}, 4-\mathrm{Pyr}), 8.56$ (d, $J=4.9 \mathrm{~Hz}, 1 \mathrm{H}, 6-\mathrm{Pyr}$ ). ${ }^{13} \mathrm{C}\left\{{ }^{1} \mathrm{H}\right\}$ NMR $\left(\mathrm{CDCl}_{3}, T=253 \mathrm{~K}, \mathrm{ppm}\right) \delta: 39.2\left(\mathrm{CH}_{3}, \mathrm{NCH}_{3}\right), 57.4$ $\left(\mathrm{CH}_{2}, \mathrm{NCH}_{2}\right), 122.3(\mathrm{CH}, \mathrm{CH}=\mathrm{CH} \mathrm{Im}), 122.7(\mathrm{CH}, \mathrm{CH}=\mathrm{CH} \mathrm{Im})$, 123.1 (CH, 5-Pyr), 123.8 (CH, 3-Pyr), 137.8 (CH, 4-Pyr), 150.3 ( $\mathrm{CH}$, 6-Pyr), 155.0 (C, 2-Pyr), 182.4 (C, NCN). Anal. Calc. for $\mathrm{C}_{10} \mathrm{H}_{11} \mathrm{AgBrN}_{3}$ : C, 33.27; $\mathrm{H}, 3.07 ; \mathrm{N}, 11.64$. Found: $\mathrm{C}, 33.35 ; \mathrm{H}$, $3.21 ; \mathrm{N}, 11.51 \%$

4.15. $\{[1-($ Phenylthio)methylene-3-mesityl]imidazolyl-2ene palladium $(0)$ (maleic anhydride) $(\mathbf{5 b})$

To the yellowish solution of $0.05 \mathrm{~g}(0.16 \mathrm{mmol})$ of $\left[\mathrm{Pd}\left(\eta^{2}-\mathrm{ma}\right)\right.$ (COD)] under inert atmosphere (Ar) in $15 \mathrm{ml}$ of anhydrous $\mathrm{CH}_{2} \mathrm{Cl}_{2}$ at $253 \mathrm{~K}$ (liquid $\mathrm{N}_{2}$ /acetone) $0.0793 \mathrm{~g}(0.16 \mathrm{mmol})$ of the silver(I) complex (3b) dissolved in $10 \mathrm{ml}$ of anhydrous $\mathrm{CH}_{2} \mathrm{Cl}_{2}$ previously cooled at $253 \mathrm{~K}$ was added in two successive aliquots ( $5 \mathrm{ml}$ each). The resulting brownish mixture was stirred for $1 \mathrm{~h}$ and the bath temperature was gradually increased to $270 \mathrm{~K}$. The precipitated $\mathrm{AgBr}$ and traces of metallic palladium were removed by Millipore filtration and the resulting yellow solution evaporated to dryness. Addition of diethylether $(20 \mathrm{ml})$ induced the precipitation of $0.0675 \mathrm{~g}$ (yield $83 \%$ ) of the title complex which was filtered off, washed with diethylether and stored at $253 \mathrm{~K}$.

${ }^{1} \mathrm{H}$ NMR $\left(\mathrm{CD}_{2} \mathrm{Cl}_{2}, T=298 \mathrm{~K}, \mathrm{ppm}\right) \delta: 2.00\left(\mathrm{~s}, 6 \mathrm{H}, 0\right.$-mesityl- $\left.\mathrm{CH}_{3}\right)$, 2.43 (s, 3H, p-mesityl $\left.\mathrm{CH}_{3}\right), 3.55$ (bs, $2 \mathrm{H}, \mathrm{CH}=\mathrm{CH}$ ma), $5.32(\mathrm{~s}, 2 \mathrm{H}$, $\left.\mathrm{SCH}_{2}\right), 7.04(\mathrm{~d}, J=1.9 \mathrm{~Hz}, 1 \mathrm{H}, \mathrm{CH}=\mathrm{CH} \mathrm{Im}), 7.09(\mathrm{~s}, 2 \mathrm{H}, m$-mesityl$\mathrm{H}), 7.27(\mathrm{~d}, J=1.9 \mathrm{~Hz}, 1 \mathrm{H}, \mathrm{CH}=\mathrm{CH} \mathrm{Im}), 7.41(\mathrm{~m}, 3 \mathrm{H}, \mathrm{SPh}), 7.65(\mathrm{~m}$, $2 \mathrm{H}, \mathrm{SPh}) .{ }^{1} \mathrm{H}$ NMR $\left(\mathrm{CD}_{2} \mathrm{Cl}_{2}, T=253 \mathrm{~K}, \mathrm{ppm}\right) \delta: 1.95(\mathrm{~s}, 3 \mathrm{H}, o-\mathrm{mesi}-$ tyl- $\left.\mathrm{CH}_{3}\right), 2.00\left(\mathrm{~s}, 3 \mathrm{H}, o\right.$-mesityl- $\left.\mathrm{CH}_{3}\right), 2.40$ (s, 3H, p-mesityl $\mathrm{CH}_{3}$ ), $3.40(\mathrm{~d}, J=3.3 \mathrm{~Hz} 1 \mathrm{H}, \mathrm{CH}=\mathrm{CH} \mathrm{ma}), 3.62(\mathrm{~d}, J=3.3 \mathrm{~Hz}, 1 \mathrm{H}, \mathrm{CH}=\mathrm{CH}$ ma), 5.30 (bs, $2 \mathrm{H}, \mathrm{SCH}_{2}$ ), 7.01 (s, 1H, m-mesityl-H), 7.04 (d, $J=1.9,1 \mathrm{H}, \mathrm{CH}=\mathrm{CH} \mathrm{Im}), 7.14(\mathrm{~s}, 1 \mathrm{H}, m$-mesityl-H), $7.26(\mathrm{~d}, J=1.9$, $1 \mathrm{H}, \mathrm{CH}=\mathrm{CH} \mathrm{Im}), 7.40(\mathrm{~m}, 3 \mathrm{H}, \mathrm{SPh}), 7.64(\mathrm{~m}, 2 \mathrm{H}, \mathrm{SPh}) .{ }^{13} \mathrm{C}\left\{{ }^{1} \mathrm{H}\right\}$ NMR $\left(\mathrm{CD}_{2} \mathrm{Cl}_{2}, T=253 \mathrm{~K}, \mathrm{ppm}\right) \delta: 17.5\left(\mathrm{CH}_{3}, o\right.$-mesityl- $\left.\mathrm{CH}_{3}\right), 17.8$ $\left(\mathrm{CH}_{3}, p\right.$-mesityl- $\left.\mathrm{CH}_{3}\right), 21.0\left(\mathrm{CH}_{3}, o\right.$-mesityl- $\left.\mathrm{CH}_{3}\right), 42.4(\mathrm{CH}, \mathrm{CH}=\mathrm{CH}$ $\mathrm{ma}), 47.1(\mathrm{CH}, \mathrm{CH}=\mathrm{CH} \mathrm{ma}), 59.9\left(\mathrm{CH}_{2}, \mathrm{SCH}_{2}\right), 118.8(\mathrm{CH}, \mathrm{CH}=\mathrm{CH}$ Im), $123.6(\mathrm{CH}, \mathrm{CH}=\mathrm{CH} \mathrm{Im}), 128.2(\mathrm{CH}, m$-mesityl-CH $), 129.2$ (CH, m-mesityl-CH), $129.5(\mathrm{CH}, \mathrm{SPh}-\mathrm{CH}), 130.0(\mathrm{CH}, \mathrm{SPh}-\mathrm{CH})$, 131.7 (C, SPh-C), 132.7 (CH, SPh-CH), 134.4 (C, o-mesityl-C), 135.6 (C, o-mesityl-C), 136.4 (C, i-mesityl-C)), 138.7 (C, $p$-mesityl-C), 173.0 (C, C=O ma), 173.2 (C, C=O ma), 190.3 (C, NCN), IR (KBr pellet, $\left.\mathrm{cm}^{-1}\right) v_{\mathrm{CO}}: 1791,1724$. Anal. Calc. for $\mathrm{C}_{24} \mathrm{H}_{24} \mathrm{~N}_{2} \mathrm{O}_{2} \mathrm{PdS}$ : C, 56.42; H, 4.73; N, 5.48. Found: C, 56.31; H, 4.83; N, 5.36\%.

The following derivatives were prepared in a similar way using the appropriate reactants.

\subsection{6. $\{[1-($ Phenylthio)methylene-3-metyl]imidazolyl-2- ene)palladium $(0)$ (maleic anhydride) $(5 \boldsymbol{a})$}

Yellow microcrystals: yield $70 \% .{ }^{1} \mathrm{H}$ NMR $\left(\mathrm{CD}_{2} \mathrm{Cl}_{2}, T=298 \mathrm{~K}\right.$, ppm) $\delta: 3.92\left(\mathrm{~s}, 3 \mathrm{H}, \mathrm{NCH}_{3}\right), 3.95$ (bs, $\left.2 \mathrm{H}, \mathrm{CH}=\mathrm{CH} \mathrm{ma}\right), 5.18(\mathrm{~s}, 2 \mathrm{H}$, $\left.\mathrm{SCH}_{2}\right), 7.09(\mathrm{bm}, 2 \mathrm{H}, \mathrm{CH}=\mathrm{CH} \mathrm{Im}), 7.41(\mathrm{~m}, 3 \mathrm{H}, \mathrm{SPh}), 7.61(\mathrm{~m}, 2 \mathrm{H}$, $\mathrm{SPh}) .{ }^{1} \mathrm{H}$ NMR $\left(\mathrm{CD}_{2} \mathrm{Cl}_{2}, T=253 \mathrm{~K}, \mathrm{ppm}\right) \delta: 3.82(\mathrm{bs}, 1 \mathrm{H}, \mathrm{CH}=\mathrm{CH}$ 
ma), 3.90 (s, 3H, $\mathrm{NCH}_{3}$ ), 4.47 (bs, $\left.1 \mathrm{H}, \mathrm{CH}=\mathrm{CH} \mathrm{ma}\right), 5.17$ (s, $2 \mathrm{H}$, $\left.\mathrm{SCH}_{2}\right), 7.10$ (bs, $\left.2 \mathrm{H}, \mathrm{CH}=\mathrm{CH} \mathrm{Im}\right), 7.39(\mathrm{~m}, 3 \mathrm{H}, \mathrm{SPh}), 7.59(\mathrm{~m}, 2 \mathrm{H}$, $\mathrm{SPh}) .{ }^{13} \mathrm{C}\left\{{ }^{1} \mathrm{H}\right\} \operatorname{NMR}\left(\mathrm{CDCl}_{3}, T=253 \mathrm{~K}, \mathrm{ppm}\right) \delta: 39.0\left(\mathrm{CH}_{3}, \mathrm{NCH}_{3}\right)$, $42.0(\mathrm{CH}, \mathrm{CH}=\mathrm{CH} \mathrm{ma}), 47.6(\mathrm{CH}, \mathrm{CH}=\mathrm{CH} \mathrm{ma}), 59.2\left(\mathrm{CH}_{2}, \mathrm{SCH}_{2}\right)$, $118.4(\mathrm{CH}, \mathrm{CH}=\mathrm{CH} \mathrm{Im}), 123.4(\mathrm{CH}, \mathrm{CH}=\mathrm{CH} \mathrm{Im}), 129.6(\mathrm{CH}, \mathrm{SPh}-$ $\mathrm{CH}), 129.9$ ( $\mathrm{CH}, \mathrm{SPh}-\mathrm{CH}), 131.7$ (C, SPh-C), 132.7 (CH, SPh-CH), 172.7 (C, $\mathrm{C}=\mathrm{O}$ ma), 172.8 (C, $\mathrm{C}=\mathrm{O} \mathrm{ma}), 188.1$ (C, NCN), IR (KBr pellet, $\mathrm{cm}^{-1}$ ) $v_{\mathrm{CO}}: 1785,1719$. Anal. Calc. for $\mathrm{C}_{16} \mathrm{H}_{16} \mathrm{~N}_{2} \mathrm{O}_{2}$ PdS: C, 47.24; H, 3.96; N, 6.89. Found: C, 47.36; H, 3.83; N, 6.73\%.

\subsection{7. $\{[1-($ Phenylthio)methylene-3-(2,6-di-i-}

propylphenyl)]imidazolyl-2-ene\}palladium( 0 ) (maleic anhydride) (5c)

Yellow microcrystals: yield 92\%. ${ }^{1} \mathrm{H}$ NMR $\left(\mathrm{CD}_{2} \mathrm{Cl}_{2}, T=298 \mathrm{~K}\right.$, ppm) $\delta: 1.10\left(\mathrm{~d}, J=6.9 \mathrm{~Hz}, 6 \mathrm{H}, i \mathrm{Pr}-\mathrm{CH}_{3}\right), 1.23(\mathrm{~d}, J=6.9 \mathrm{~Hz}, 6 \mathrm{H}$, $\left.i \mathrm{Pr}-\mathrm{CH}_{3}\right), 2.47$ (bm, $\left.2 \mathrm{H}, i \mathrm{Pr}-\mathrm{CH}\right), 3.61$ (bs, $\left.2 \mathrm{H}, \mathrm{CH}=\mathrm{CH} \mathrm{ma}\right), 5.33$ (s, $\left.2 \mathrm{H}, \mathrm{SCH}_{2}\right), 7.10(\mathrm{~d}, J=1.9 \mathrm{~Hz}, 1 \mathrm{H}, \mathrm{CH}=\mathrm{CH} \mathrm{Im}), 7.27(\mathrm{~d}, J$ $=1.9 \mathrm{~Hz}, 1 \mathrm{H}, \mathrm{CH}=\mathrm{CH} \mathrm{Im}), 7.36(\mathrm{~d}, J=7.7 \mathrm{~Hz}, 2 \mathrm{H}, m$-aryl-H $), 7.43$ $(\mathrm{m}, 3 \mathrm{H}, \mathrm{SPh}-\mathrm{CH}), 7.56(\mathrm{t}, J=7.7 \mathrm{~Hz}, 1 \mathrm{H}, p$-aryl- $\mathrm{H}),, 7.64(\mathrm{~m}, 2 \mathrm{H}$, $\mathrm{SPh}-\mathrm{CH}) .{ }^{13} \mathrm{C}\left\{{ }^{1} \mathrm{H}\right\}$ NMR $\left(\mathrm{CDCl}_{3}, T=298 \mathrm{~K}, \mathrm{ppm}\right) \delta: 23.2\left(\mathrm{CH}_{3}, \mathrm{PPr}-\right.$ $\left.\mathrm{CH}_{3}\right), 24.7\left(\mathrm{CH}_{3}, i \mathrm{Pr}-\mathrm{CH}_{3}\right), 28.4\left(\mathrm{CH}_{3}, i \mathrm{Pr}-\mathrm{CH}\right), 59.1\left(\mathrm{CH}_{2}, \mathrm{SCH}_{2}\right)$, $118.2(\mathrm{CH}, \mathrm{CH}=\mathrm{CH} \mathrm{Im}), 124.8(\mathrm{CH}, \mathrm{CH}=\mathrm{CH} \mathrm{Im}), 124.0(\mathrm{CH}, m-$ aryl-CH), $129.6(\mathrm{CH}, \mathrm{SPh}-\mathrm{CH}), 129.8(\mathrm{CH}, p$-aryl-CH $), 129.9(\mathrm{CH}$, $\mathrm{SPh}-\mathrm{CH}), 131.54$ (C, SPh-C), $132.0(\mathrm{CH}, \mathrm{SPh}-\mathrm{CH}), 135.9$ (C, $i$-arylC), 144.9 (C, o-aryl-C), 192.5 (C, NCN). ${ }^{1} \mathrm{H} \mathrm{NMR}\left(\mathrm{CD}_{2} \mathrm{Cl}_{2}, T=253 \mathrm{~K}\right.$, ppm) $\delta$ : 1.07 (bs, $6 \mathrm{H}, \mathrm{iPr}-\mathrm{CH}_{3}$ ), 1.18 (bd, $J=6.5 \mathrm{~Hz}, 3 \mathrm{H}, \mathrm{iPr}-\mathrm{CH}_{3}$ ), 1.26 (bd, $J=7.4 \mathrm{~Hz}, 3 \mathrm{H}$, iPr- $\mathrm{CH}_{3}$ ), $2.28(\mathrm{bm}, 1 \mathrm{H}, i \mathrm{Pr}-\mathrm{CH}), 2.50$ (bm, $1 \mathrm{H}, i \mathrm{Pr}-\mathrm{CH}$ ), 3.58 (bd, $J=3.1 \mathrm{~Hz}, 1 \mathrm{H}, \mathrm{CH} \mathrm{ma}$ ), 3.77 (bd, $J=3.1 \mathrm{~Hz}, 1 \mathrm{H}, \mathrm{CH} \mathrm{ma}), 5.24\left(\mathrm{~d}, J=12.1 \mathrm{~Hz}, 1 \mathrm{H}, \mathrm{CH}_{2} \mathrm{~S}\right), 5.31$ (d, $\left.J=12.6 \mathrm{~Hz}, 1 \mathrm{H}, \mathrm{CH}_{2} \mathrm{~S}\right), 7.07(\mathrm{~d}, J=1.7 \mathrm{~Hz}, 1 \mathrm{H} \mathrm{CH}=\mathrm{CH} \mathrm{Im}), 7.26(\mathrm{~d}$, $J=1.8 \mathrm{~Hz}, 1 \mathrm{H} \mathrm{CH}=\mathrm{CH} \mathrm{Im}), 7.32-7.41(\mathrm{~m}, 5 \mathrm{H}, \mathrm{CH} \mathrm{Ph}, \mathrm{DiPPh}), 7.55-$ $7.62(\mathrm{~m}, 3 \mathrm{H}, \mathrm{CH} \mathrm{Ph}, \mathrm{DiPPh}) .{ }^{13} \mathrm{C}$ NMR $\left(\mathrm{CD}_{2} \mathrm{Cl}_{2}, T=253 \mathrm{~K}, \mathrm{ppm}\right) \delta$ : $23.2\left(\mathrm{CH}_{3}, i \mathrm{Pr}-\mathrm{CH}_{3}\right), 23.5\left(\mathrm{CH}_{3}, i \mathrm{Pr}-\mathrm{CH}_{3}\right), 24.8\left(\mathrm{CH}_{3}, i \mathrm{Pr}-\mathrm{CH}_{3}\right), 25.0$ $\left(\mathrm{CH}_{3}, i \mathrm{Pr}-\mathrm{CH}_{3}\right), 28.3(\mathrm{CH}, i \mathrm{Pr}-\mathrm{CH}), 28.4(\mathrm{CH}, i \mathrm{Pr}-\mathrm{CH}), 43.3(\mathrm{CH}$, $\mathrm{Ma}), 47.9(\mathrm{CH}, \mathrm{Ma}), 59.5\left(\mathrm{CH}_{2}, \mathrm{CH}_{2} \mathrm{~S}\right), 118.6(\mathrm{CH}, \mathrm{CH}=\mathrm{CH} \mathrm{Im})$, $123.5(\mathrm{CH}, \mathrm{CH}=\mathrm{CH} \mathrm{Im}), 124.5$ ( $\mathrm{CH}, m$-DiPP), 124.8 ( $\mathrm{CH}, m$-DiPP), 129.7 (CH, o-Ph-C), 130.0 (CH, p-DiPP), 130.1 (CH, p-Ph-C), 131.4 (C, $i$-Ph),132.5 (CH, m-Ph-C), 135.8 (C, $i$-DiPP), 144.5 (C, o-DiPPC), 145.3 (C, o-DiPP-C), 171.2 (CO, Ma), 173.7 (CO, Ma), 191.3 (C, NHC). IR ( $\mathrm{KBr}$ pellet, $\mathrm{cm}^{-1}$ ) $v_{\mathrm{CO}}: 1790,1720$. Anal. Calc. for $\mathrm{C}_{27} \mathrm{H}_{30} \mathrm{~N}_{2} \mathrm{O}_{2} \mathrm{PdS}$ : C, 58.64; $\mathrm{H}, 5.47 ; \mathrm{N}, 5.07$. Found: C, 58.77; $\mathrm{H}$, 5.59; N, 5.21\%.

\subsection{8. \{[1-(2-Pyridyl)methylene-3-methyl ]imidazolyl-2- ene\}palladium $(0)$ (maleic anhydride) (6a)}

Yellow microcrystals: yield 95\%. ${ }^{1} \mathrm{H}$ NMR $\left(\mathrm{CD}_{2} \mathrm{Cl}_{2}, T=298 \mathrm{~K}\right.$, ppm) $\delta$ : $3.58(\mathrm{~d}, J=3.2 \mathrm{~Hz}, 1 \mathrm{H}, \mathrm{CH}=\mathrm{CH} \mathrm{ma}), 3.76\left(\mathrm{~s}, 3 \mathrm{H}, \mathrm{NCH}_{3}\right)$,), $4.13(\mathrm{~d}, J=3.2 \mathrm{~Hz}, 1 \mathrm{H}, \mathrm{CH}=\mathrm{CH} \mathrm{ma}), 4.98,5.22$ (AB system, $1 \mathrm{H}$, $\left.J=14.4 \mathrm{~Hz}, \mathrm{SCH}_{2}\right), 6.95(\mathrm{~d}, J=1.8 \mathrm{~Hz}, 1 \mathrm{H}, \mathrm{CH}=\mathrm{CH} \mathrm{Im}), 7.07(\mathrm{~d}$, $J=1.8 \mathrm{~Hz}, 1 \mathrm{H}, \mathrm{CH}=\mathrm{CH} \mathrm{Im}$ ), 7.42 (ddd, $J=7.6,5.3,1.7 \mathrm{~Hz}, 1 \mathrm{H}, 5-$ Pyr), 7.51 (d, $J=7.6 \mathrm{~Hz}, 1 \mathrm{H}, 3-\mathrm{Pyr}$ ), 7.87 (td, $J=7.6,1.7 \mathrm{~Hz}, 1 \mathrm{H}, 4-$ Pyr), 8.88 (dd, $J=5.3,0.9 \mathrm{~Hz}, 1 \mathrm{H}, 6-\mathrm{Pyr}),{ }^{13} \mathrm{C}\left\{{ }^{1} \mathrm{H}\right\}$ NMR $\left(\mathrm{CD}_{2} \mathrm{Cl}_{2}\right.$, $T=298 \mathrm{~K}, \mathrm{ppm}) \delta: 37.7\left(\mathrm{CH}_{3}, \mathrm{~N} \mathrm{CH}_{3}\right), 40.1(\mathrm{CH}, \mathrm{CH}=\mathrm{CH} \mathrm{ma}), 41.3$ $(\mathrm{CH}, \mathrm{CH}=\mathrm{CH}$ ma $), 55.3\left(\mathrm{CH}_{2}, \mathrm{NCH}_{2}\right), 120.7(\mathrm{CH}, \mathrm{CH}=\mathrm{CH} \mathrm{Im}), 120.8$ $(\mathrm{CH}, \mathrm{CH}=\mathrm{CH} \mathrm{Im}), 124.4(\mathrm{CH}, 3-\mathrm{Pyr}), 124.7(\mathrm{CH}, 5-\mathrm{Pyr}), 138.4(\mathrm{CH}$, 4-Pyr), 153.1 (CH, 6-Pyr), 153.2 (C, 2-Pyr), 174.0 (C, C=O ma), 186.0 (C, NCN). IR ( $\mathrm{KBr}$ pellet, $\mathrm{cm}^{-1}$ ) $v_{\mathrm{CO}}: 1779,1714$. Anal. Calc. for $\mathrm{C}_{15} \mathrm{H}_{15} \mathrm{~N}_{3} \mathrm{O}_{2} \mathrm{Pd}$ : C, 47.95; $\mathrm{H}, 4.02 ; \mathrm{N}, 11.18$. Found: $\mathrm{C}, 47.84 ; \mathrm{H}$, 4.18; N, $11.01 \%$.

4.19. \{[1-(2-Pyridyl)methylene-3-mesityl]imidazolyl-2ene palladium $(0)$ (maleic anhydride) $(\boldsymbol{6 b})$

Yellow microcrystals: yield 95\%. ${ }^{1} \mathrm{H}$ NMR $\left(\mathrm{CD}_{2} \mathrm{Cl}_{2}, T=298 \mathrm{~K}\right.$, ppm) $\delta: 1.94$ (bs, 3H, o-mesityl- $\mathrm{CH}_{3}$ ), 2.07 (bs, 3H, o-mesityl-
$\mathrm{CH}_{3}$ ), 2.40 (s, 3H, p-mesityl- $\mathrm{CH}_{3}$ ), 3.12 (bs, $1 \mathrm{H}, \mathrm{CH}=\mathrm{CH}$ ma), 3.31 (bs, $1 \mathrm{H}, \mathrm{CH}=\mathrm{CH} \mathrm{ma}$ ), 5.13, 5.43 (AB system, $J=14.8 \mathrm{~Hz}, 1 \mathrm{H}$, $\left.\mathrm{NCH}_{2}\right), 6.94(\mathrm{~d}, J=1.8 \mathrm{~Hz}, 1 \mathrm{H}, \mathrm{CH}=\mathrm{CH} \mathrm{Im}), 7.03(\mathrm{~m}, 2 \mathrm{H}, m$-mesiyl-H), $7.26(\mathrm{~d}, J=1.8 \mathrm{~Hz}, 1 \mathrm{H}, \mathrm{CH}=\mathrm{CH} \mathrm{Im}$ ), 7.39 (ddd, $J=7.6,5.3$, $1.7 \mathrm{~Hz}, 1 \mathrm{H}, 5-\mathrm{Pyr}$ ), 7.56 (d, $J=7.6 \mathrm{~Hz}, 1 \mathrm{H}, 5$-Pyr), 7.89 (td, $J=7.6$, $1.7 \mathrm{~Hz}, 1 \mathrm{H}, 4-\mathrm{Pyr}$ ), 8.96 (dd, $J=1.0,5.3 \mathrm{~Hz}, 1 \mathrm{H}, 6$-Pyr), IR (KBr pellet, $\mathrm{cm}^{-1}$ ) $v_{\mathrm{CO}}: 1785,1715$. Anal. Calc. for $\mathrm{C}_{23} \mathrm{H}_{23} \mathrm{~N}_{3} \mathrm{O}_{2} \mathrm{Pd}: \mathrm{C}, 57.57 ; \mathrm{H}$, 4.83; N, 8.76. Found: C, 57.42; H, 4.95; N, 8.64\%.

4.20. \{[1-(2-Pyridyl)methylene-3-mesityl]imidazolyl-2ene\}palladium $(0)$ (naphthoquinone) $(\mathbf{7 b})$

To a solution of [2-methyl-6-(phenylthiomethyl)pyridine]palladium $(0)$ (naphthoquinone) $(0.050 \mathrm{~g}, 0.10 \mathrm{mmol})$ in dichloromethane $(10 \mathrm{ml})$ was added a solution of $\{[1$-(2-pyridyl)methylene-3mesityl]imidazolyl-2-ene $\}$ silver bromide $(\mathbf{4 b})(0.046 \mathrm{~g}, 0.10 \mathrm{mmol})$ in $10 \mathrm{ml}$ in the same solvent. Immediate precipitation of silver bromide was observed. After a half hour the reaction mixture was filtered through Celite and concentrated to a small volume at reduced pressure. The slow addition of diethylether gave the precipitation of the product as microcrystalline red-orange solid (0.044 g, 82\%).

${ }^{1} \mathrm{H}$ NMR $\left(\mathrm{CD}_{2} \mathrm{Cl}_{2} \mathrm{~T}=253 \mathrm{~K}, \mathrm{ppm}\right) \delta: 1.46\left(\mathrm{~s}, 3 \mathrm{H}, \mathrm{o}\right.$-mesityl- $\left.\mathrm{CH}_{3}\right)$, 1.99 (s, 3H, o-mesityl- $\mathrm{CH}_{3}$ ), 2.47 (s, 3H, p-mesityl- $\mathrm{CH}_{3}$ ), 4.18, 4.36 (AB system, $J=6.7 \mathrm{~Hz}, 2 \mathrm{H}, \mathrm{CH}=\mathrm{CH} n q$ ), 5.04, 5.24 (AB system, $\left.J=14.6 \mathrm{~Hz}, 2 \mathrm{H}, \mathrm{NCH}_{2}\right), 6.76(\mathrm{~d}, J=1.8 \mathrm{~Hz}, 1 \mathrm{H}, \mathrm{CH}=\mathrm{CH} \mathrm{Im}), 6.87$ (bs, 1H, m-mesityl-H), 7.07 (bs, 1H, m-mesityl-H), 7.21 (d, $J=1.8 \mathrm{~Hz}, 1 \mathrm{H}, \mathrm{CH}=\mathrm{CH} \mathrm{Im}), 7.33-7.50(\mathrm{~m}, 5 \mathrm{H}, 3-\mathrm{Pyr}, 5-\mathrm{Pyr}, \mathrm{CH}-$ nq), $7.84(\mathrm{td}, J=7.7,1.7 \mathrm{~Hz}, 1 \mathrm{H}, 4-\mathrm{Pyr}), 7.92(\mathrm{~d}, J=7.4 \mathrm{~Hz}, 1 \mathrm{H}, \mathrm{CH}-$ nq), 8.47 (d, $J=4.5 \mathrm{~Hz}, 1 \mathrm{H}, 6-\mathrm{Pyr})$,

${ }^{13} \mathrm{C}$ NMR $\left(\mathrm{CD}_{2} \mathrm{Cl}_{2}, T=253 \mathrm{~K}, \mathrm{ppm}\right) \delta: 17.3\left(\mathrm{CH}_{3}, o\right.$-mesityl $), 18.0$ $\left(\mathrm{CH}_{3}, 0\right.$-mesityl $), 21.4\left(\mathrm{CH}_{3}, p\right.$-mesityl $), 55.5\left(\mathrm{CH}_{2}-\mathrm{Py}\right), 58.7(\mathrm{CH}=\mathrm{CH}$ $\mathrm{nq}), 65.5(\mathrm{CH}=\mathrm{CH} \mathrm{nq}), 121.1(\mathrm{CH}=\mathrm{CH} \mathrm{Im}), 122.0(\mathrm{CH}=\mathrm{CH} \mathrm{Im}), 123.6$ (CH, 3-Py), 124.0 (CH, 5-Py), 125.3 (CH, Nq), 125.5 (CH, Nq), 128.8 (CH, m-mesityl), 129.4 (C, p-mesityl), 130.6 (CH, m-mesityl), 134.9 (C, o-mesityl), 135.2 (CH, Nq), 135.4 (C, o-mesityl), 135.8 (CH, Nq), 137.5 (C, i-mesityl), 138.1 (CH, 4-Py), 138.5 (C, Nq), 150.7 (CH, 6Py), 152.3 (C, 2-Py), 174.1 (CO), 183.8 (CO), 187.0 (C, NHC). IR (KBr pellet, $\left.\mathrm{cm}^{-1}\right) v_{\mathrm{CO}}: 1790,1720$. Anal. Calc. for $\mathrm{C}_{28} \mathrm{H}_{25} \mathrm{~N}_{3} \mathrm{O}_{2} \mathrm{Pd}: \mathrm{C}$, 62.06; H, 4.65; N, 7.75. Found: C, 62.14; H, 4.51; N, 7.88\%.

The following derivatives were prepared in a similar way using the appropriate silver complex.

\subsection{1. \{[1-(2-Pyridyl)methylene-3-metyl]imidazolyl-2-} ene\}palladium(0)(naphthoquinone) (7a)

Red-orange microcrystals: yield $64 \% .{ }^{1} \mathrm{H}$ NMR $\left(\mathrm{CD}_{2} \mathrm{Cl}_{2} T=253 \mathrm{~K}\right.$, ppm) $\delta: 3.54\left(\mathrm{~s}, 3 \mathrm{H}, \mathrm{NCH}_{3}\right), 4.88,4.54$ (AB system, $J=6.7 \mathrm{~Hz}, 2 \mathrm{H}$, $\mathrm{CH}=\mathrm{CH} \mathrm{nq}), 4.89,5.17\left(\mathrm{AB}\right.$ system, $\left.J=14.5 \mathrm{~Hz}, 2 \mathrm{H}, \mathrm{NCH}_{2}\right), 6.83$ $(\mathrm{d}, J=1.7 \mathrm{~Hz}, 1 \mathrm{H}, \mathrm{CH}=\mathrm{CH} \mathrm{Im}), 7.02(\mathrm{~d}, J=1.7 \mathrm{~Hz}, 1 \mathrm{H}, \mathrm{CH}=\mathrm{CH} \mathrm{Im})$, 7.43-7.53 (m, 4H, 3-Pyr, 5-Pyr, CH-nq), 7.81 (td, $J=7.6,1.6 \mathrm{~Hz}$, 1H, 4-Pyr), 8.01-8.04 (m, 2H, CH-nq), 8.08-8.11 (m, 2H, CH-nq), $8.39(\mathrm{~d}, J=5.1 \mathrm{~Hz}, 1 \mathrm{H}, 6-\mathrm{Pyr}),{ }^{13} \mathrm{C}\left\{{ }^{1} \mathrm{H}\right\}$ NMR $\left(\mathrm{CDCl}_{3}, T=298 \mathrm{~K}\right.$, ppm) $\delta: 37.0\left(\mathrm{CH}_{3}, \mathrm{NCH}_{3}\right), 55.3\left(\mathrm{CH}_{2}, \mathrm{NCH}_{2}\right), 61.0(\mathrm{CH}, \mathrm{CH}=\mathrm{CH}$ nq), $63.8(\mathrm{CH}, \mathrm{CH}=\mathrm{CH} \mathrm{nq}), 120.4(\mathrm{CH}, \mathrm{CH}=\mathrm{CH} \mathrm{Im}), 121.4(\mathrm{CH}$, $\mathrm{CH}=\mathrm{CH} \mathrm{Im}), 123.8(\mathrm{CH}, 5-\mathrm{Pyr}), 124.0(\mathrm{CH}, \mathrm{CH}-\mathrm{nq}) 125.3(\mathrm{CH}, 3-$ Pyr), 130.3 (CH, CH-nq), 130.8 (CH, CH-nq), 137.9 (CH, 4-Pyr), 149.6 (CH, 2-Pyr), 150.9 (CH, 6-Pyr), 180.8(C, CO),188.7 (C, NCN). IR ( $\mathrm{KBr}$ pellet, $\mathrm{cm}^{-1}$ ) $v_{\mathrm{CO}}$ : 1633. Anal. Calc. for $\mathrm{C}_{20} \mathrm{H}_{17} \mathrm{~N}_{3} \mathrm{O}_{2} \mathrm{Pd}$ : C, 54.87; H, 3.91; N, 9.60. Found: C, 54.72; H, 3.79; N, 9.74\%.

4.22. \{[1-(2-Pyridyl)methylene-3-(2,6-di-i-propylphenyl)]imidazolyl2-ene\}palladium $(0)$ (naphthoquinone) (7c)

Red-orange microcrystals, yield 68\%. ${ }^{1} \mathrm{H}$ NMR $\left(\mathrm{CD}_{2} \mathrm{Cl}_{2}, T=253 \mathrm{~K}\right.$, ppm) $\delta: 0.20\left(\mathrm{~d}, J=6.8 \mathrm{~Hz}, 3 \mathrm{H}, i \mathrm{Pr}-\mathrm{CH}_{3}\right), 0.75(\mathrm{~d}, J=6.8 \mathrm{~Hz}, 3 \mathrm{H}$, 
$\left.i \mathrm{Pr}-\mathrm{CH}_{3}\right), 1.10\left(\mathrm{~d}, J=6.8 \mathrm{~Hz}, 3 \mathrm{H}, i \mathrm{Pr}-\mathrm{CH}_{3}\right), 1.50(\mathrm{~d}, J=6.8 \mathrm{~Hz}, 3 \mathrm{H}$, $i \mathrm{Pr}-\mathrm{CH}_{3}$ ), 1.54 (sept, $J=6.8 \mathrm{~Hz}, 1 \mathrm{H}, i \mathrm{Pr}-\mathrm{CH}$ ), 2.60 (sept, $J=6.8 \mathrm{~Hz}$, $1 \mathrm{H}, i \mathrm{Pr}-\mathrm{CH}$ ), 4.42, 4.46 ( $\mathrm{AB}$ system, $J=6.8 \mathrm{~Hz}, 2 \mathrm{H}, \mathrm{CH}=\mathrm{CH} \mathrm{nq}$ ), $5.42,5.02$ (AB system, $\left.J=14.4 \mathrm{~Hz}, 2 \mathrm{H}, \mathrm{NCH}_{2}\right), 6.84(\mathrm{~d}, J=1.7 \mathrm{~Hz}$, $1 \mathrm{H}, \mathrm{CH}=\mathrm{CH} \mathrm{Im}), 6.98(\mathrm{~d}, J=7.7 \mathrm{~Hz}, 2 \mathrm{H}, m$-aryl-H), 7.19 (d, $J=1.7 \mathrm{~Hz}, 1 \mathrm{H}, \mathrm{CH}=\mathrm{CH} \mathrm{Im}), 7.31-7.49(\mathrm{~m}, 6 \mathrm{H}, m$-aryl-H, 3-pyr, 5Pyr, CH-nq), 7.59 (t, $J=7.8 \mathrm{~Hz}, 1 \mathrm{H}, p$-aryl-H), 7.81 (td, $J=7.6$, $1.5 \mathrm{~Hz}, 1 \mathrm{H}, 4-\mathrm{Pyr}$ ), 8.02 (d, J=6.9 Hz, 1H, CH-nq), 8.37 (d, $J=4.4 \mathrm{~Hz}, 1 \mathrm{H}, 6-\mathrm{Pyr}),{ }^{13} \mathrm{C}\left\{{ }^{1} \mathrm{H}\right\}$ NMR $\left(\mathrm{CD}_{2} \mathrm{Cl}_{2}, T=253 \mathrm{~K}, \mathrm{ppm}\right) \delta$ : $22.2\left(\mathrm{CH}_{3}, i \mathrm{Pr}-\mathrm{CH}_{3}\right), 22.7\left(\mathrm{CH}_{3}, i \mathrm{Pr}-\mathrm{CH}_{3}\right), 22.2\left(\mathrm{CH}_{3}, i \mathrm{Pr}-\mathrm{CH}_{3}\right), 24.0$ $\left(\mathrm{CH}_{3}, i \mathrm{Pr}-\mathrm{CH}_{3}\right), 27.8(\mathrm{CH}, i \mathrm{Pr}-\mathrm{CH}), 28.6(\mathrm{CH}, i \mathrm{Pr}-\mathrm{CH}), 55.6\left(\mathrm{CH}_{2}\right.$, $\left.\mathrm{NCH}_{2}\right), 57.2(\mathrm{CH}, \mathrm{CH}=\mathrm{CH} \mathrm{nq}), 64.2(\mathrm{CH}, \mathrm{CH}=\mathrm{CH} \mathrm{nq}), 120.8(\mathrm{CH}$, $\mathrm{CH}=\mathrm{CH} \mathrm{Im}), 123.1(\mathrm{CH}, \mathrm{CH}=\mathrm{CH} \mathrm{Im}), 123.9(\mathrm{CH}, m$-aryl- $\mathrm{CH}), 124.0$ (CH, CH-nq) $125.4(\mathrm{CH}, 3-\mathrm{Pyr}), 125.9(\mathrm{CH}, 5-\mathrm{pyr}), 129.4(\mathrm{CH}$, p-aryl-CH), 130.0 (CH, CH-nq), 130.8 (CH, CH-nq), 135.1 (C, $i$-aryl-C), 135.5 (C, C-nq), 137.2 (C, C-nq), 138.0 (CH, 4-Pyr), 144.9 (C, o-aryl-C), 145.2 (C, o-aryl-C), 150.1 (C, 6-Pyr), 152.2 (CH, 2Pyr), 176.7 (C, C=O), 185.4 (C, C=O), 189.1 (C, NCN). IR (KBr pellet, $\mathrm{cm}^{-1}$ ) $v_{\mathrm{CO}}$ : 1641. Anal. Calc. for $\mathrm{C}_{31} \mathrm{H}_{31} \mathrm{~N}_{3} \mathrm{O}_{2}$ Pd: C, 63.75; $\mathrm{H}, 5.35 ; \mathrm{N}$, 7.20. Found: C, 63.88; H, 5.49; N, 7.07\%.

4.23. $\{[1-(2-P y r i d y l) m e t h y l e n e-3-m e s i t y l] i m i d a z o l y l-2-$

ene\}palladium $(0)$ (tetramethyl ethene tetracarboxylate) $(\mathbf{8 b})$

To a solution of [2-methyl-6-(phenylthiomethyl)pyridine]palla$\operatorname{dium}(0)$ (tetramethyl ethene tetracarboxylate) $(0.050 \mathrm{~g}$, $0.09 \mathrm{mmol})$ in dichloromethane $(10 \mathrm{ml})$ was added a solution of \{[1-(2-pyridyl)methylene-3-mesetyl]imidazolyl-2-ene\}silver bromide $(\mathbf{4 b})(0.040 \mathrm{~g}, 0.09 \mathrm{mmol})$ in $10 \mathrm{ml}$ of the same solvent. Immediate precipitation of silver bromide was observed. After a half hour the reaction mixture was filtered through a pad of Celite and concentrated to a small volume at reduced pressure. The slow addition of diethyl ether gave the precipitation of the product as microcrystalline yellow solid $(0.041 \mathrm{~g}, 74 \%) .{ }^{1} \mathrm{H}$ NMR $\left(\mathrm{CD}_{2} \mathrm{Cl}_{2}\right.$, $T=298 \mathrm{~K}, \mathrm{ppm}) \delta: 2.01\left(\mathrm{~s}, 6 \mathrm{H}, o\right.$-mesityl- $\left.\mathrm{CH}_{3}\right), 2.34$ (s, 3H, $p$-mesityl- $\left.\mathrm{CH}_{3}\right), 3.29\left(\mathrm{~s}, 6 \mathrm{H}, \mathrm{OCH}_{3}\right), 3.49\left(\mathrm{~s}, 6 \mathrm{H}, \mathrm{OCH}_{3}\right), 5.29\left(\mathrm{~s}, 2 \mathrm{H}, \mathrm{NCH}_{2}\right)$, $6.77(\mathrm{~d}, J=1.8 \mathrm{~Hz}, 1 \mathrm{H}, \mathrm{CH}=\mathrm{CH} \mathrm{Im}), 6.95(\mathrm{~s}, 2 \mathrm{H}, m$-mesityl-H), 7.25 (d, $J=1.8 \mathrm{~Hz}, 1 \mathrm{H}, \mathrm{CH}=\mathrm{CH} \mathrm{Im}$ ), 7.40 (ddd, $J=7.6,4.3,1.3 \mathrm{~Hz}, 1 \mathrm{H}, 5-$ Pyr), 7.52 (d, $J=7.6 \mathrm{~Hz}, 1 \mathrm{H}, 3-\mathrm{Pyr}), 7.84$ (td, $J=7.6,1.7 \mathrm{~Hz}, 1 \mathrm{H}, 4-$ Pyr), $9.60(\mathrm{~d}, J=4.3 \mathrm{~Hz}, 1 \mathrm{H}, 6-\mathrm{Pyr}),{ }^{13} \mathrm{C}\left\{{ }^{1} \mathrm{H}\right\}$ NMR $\left(\mathrm{CD}_{2} \mathrm{Cl}_{2}\right.$, $T=298 \mathrm{~K}, \mathrm{ppm}) \delta: 17.4\left(\mathrm{CH}_{3}, o\right.$-mesityl- $\left.\mathrm{CH}_{3}\right), 20.6\left(\mathrm{CH}_{3}, p\right.$-mesityl- $\left.\mathrm{CH}_{3}\right), 51.1\left(\mathrm{CH}_{3}, \mathrm{OCH}_{3}\right), 55.6\left(\mathrm{CH}_{2}, \mathrm{NCH}_{2}\right), 120.8(\mathrm{CH}, \mathrm{CH}=\mathrm{CH}$ $\mathrm{Im}), 121.6(\mathrm{CH}, \mathrm{CH}=\mathrm{CH} \mathrm{Im}), 123.7(\mathrm{CH}, 3-\mathrm{Pyr}), 124.1(\mathrm{CH}, 5-\mathrm{Pyr})$, 128.6 ( $\mathrm{CH}, \mathrm{m}$-mesityl-CH), 135.3 (C, o-mesityl-C), 135.9 (C, $i$-mesityl-C), 137.8 ( $\mathrm{CH}, 4$-Pyr), 137.9 (C, p-mesityl-C), 153.4 (C, 2-Pyr), 155.3 ( CH, 6-Pyr), 170.5 (C, C=0), 170.6 (C, C=O), 188.6 (C, NCN).

IR $\left(\mathrm{KBr}\right.$ pellet, $\left.\mathrm{cm}^{-1}\right) \quad v_{\mathrm{CO}}=1724,1682$. Anal. Calc. for $\mathrm{C}_{28} \mathrm{H}_{23} \mathrm{~N}_{3} \mathrm{O}_{8} \mathrm{Pd}: \mathrm{C}, 52.22 ; \mathrm{H}, 4.85 ; \mathrm{N}, 6.53$. Found: C, 52.08; $\mathrm{H}$, $4.71 ; \mathrm{N}, 6.41 \%$.

The following derivatives were prepared in a similar way using the appropriate silver complex.

4.24. \{[1-(2-Pyridyl)methylene-3-metyl]imidazolyl-2-

ene palladium $(0)$ (tetramethyl ethene tetracarboxylate) $(\mathbf{8 a})$

Yellow microcrystals: yield $64 \% .{ }^{1} \mathrm{H}$ NMR $\left(\mathrm{CD}_{2} \mathrm{Cl}_{2}, T=298 \mathrm{~K}\right.$, ppm) $\delta: 3.60\left(\mathrm{~s}, 6 \mathrm{H}, \mathrm{OCH}_{3}\right), 3.63\left(\mathrm{~s}, 6 \mathrm{H}, \mathrm{OCH}_{3}\right), 3.76\left(\mathrm{~s}, 3 \mathrm{H}, \mathrm{NCH}_{3}\right)$, $5.12\left(\mathrm{~s}, 2 \mathrm{H}, \mathrm{NCH}_{2}\right), 6.92(\mathrm{~d}, J=1.8 \mathrm{~Hz}, 1 \mathrm{H}, \mathrm{CH}=\mathrm{CH} \mathrm{Im}), 7.06(\mathrm{~d}$, $J=1.8 \mathrm{~Hz}, 1 \mathrm{H}, \mathrm{CH}=\mathrm{CH} \mathrm{Im}$ ), 7.41 (ddd, $J=7.6,4.6,1.0 \mathrm{~Hz}, 1 \mathrm{H}, 5-$ Pyr), 7.47 (d, $J=7.6 \mathrm{~Hz}, 1 \mathrm{H}, 3-\mathrm{Pyr}), 7.84(\mathrm{td}, J=7.6,1.6 \mathrm{~Hz}, 1 \mathrm{H}, 4-$ Pyr), $9.63(\mathrm{~d}, J=4.6 \mathrm{~Hz}, 1 \mathrm{H}, 6-\mathrm{Pyr}),{ }^{13} \mathrm{C}\left\{{ }^{1} \mathrm{H}\right\}$ NMR $\left(\mathrm{CD}_{2} \mathrm{Cl}_{2}\right.$, $T=298 \mathrm{~K}, \mathrm{ppm}) \delta: 37.4\left(\mathrm{CH}_{3}, \mathrm{NCH}_{3}\right), 51.3\left(\mathrm{CH}_{3}, \mathrm{OCH}_{3}\right), 51.5\left(\mathrm{CH}_{3}\right.$, $\left.\mathrm{OCH}_{3}\right), 55.2\left(\mathrm{CH}_{2}, \mathrm{NCH}_{2}\right), 120.6(\mathrm{CH}, \mathrm{CH}=\mathrm{CH} \mathrm{Im}), 120.9(\mathrm{CH}$, $\mathrm{CH}=\mathrm{CH} \mathrm{Im}), 124.0(\mathrm{CH}, 5-\mathrm{Pyr}), 124.4(\mathrm{CH}, 3-\mathrm{Pyr}), 138.1(\mathrm{CH}, 4-$
Pyr), 153.4 (C, 2-Pyr), 155.7 (CH, 6-Pyr), 170.5 (C, C=0), 171.1 (C $\mathrm{C}=\mathrm{O}), 185.2$ (C, NCN). IR ( $\mathrm{KBr}$ pellet, $\left.\mathrm{cm}^{-1}\right) v_{\mathrm{CO}}: 1707,1681$. Anal. Calc. for $\mathrm{C}_{20} \mathrm{H}_{23} \mathrm{~N}_{3} \mathrm{O}_{8} \mathrm{Pd}$ : C, 44.50; $\mathrm{H}, 4.29 ; \mathrm{N}, 7.78$. Found: $\mathrm{C}$, $44.63 ; \mathrm{H}, 4.37$; N, 7.65\%.

4.25. \{[1-(2-Pyridyl)methylene-3-(2,6-di-i-propylphenyl)]imidazolyl2-ene\}palladium $(0)$ (tetramethyl ethene tetracarboxylate) (8c)

Yellow microcrystals: yield $71 \% .{ }^{1} \mathrm{H}$ NMR $\left(\mathrm{CD}_{2} \mathrm{Cl}_{2}, T=298 \mathrm{~K}\right.$, ppm) $\delta: 1.01\left(\mathrm{~d}, J=6.8 \mathrm{~Hz}, 6 \mathrm{H}, i \mathrm{Pr}-\mathrm{CH}_{3}\right), 1.31(\mathrm{~d}, J=6.8 \mathrm{~Hz}, 6 \mathrm{H}$, iPr- $\mathrm{CH}_{3}$ ), 2.43 (bm, $2 \mathrm{H}, i \mathrm{Pr}-\mathrm{CH}$ ), 3.21 (bs, $6 \mathrm{H}, \mathrm{OCH}_{3}$ ), 3.45 (s, $6 \mathrm{H}$, $\left.\mathrm{OCH}_{3}\right), 5.34\left(\mathrm{~s}, 2 \mathrm{H}, \mathrm{NCH}_{2}\right), 6.83(\mathrm{~d}, J=1.6 \mathrm{~Hz}, 1 \mathrm{H}, \mathrm{CH}=\mathrm{CH} \mathrm{Im})$, $7.21(\mathrm{~d}, J=1.8 \mathrm{~Hz}, 1 \mathrm{H}, \mathrm{CH}=\mathrm{CH} \mathrm{Im}), 7.22(\mathrm{~d}, J=7.7 \mathrm{~Hz}, 2 \mathrm{H}, m$-arylH), 7.37 ( $\mathrm{m}, 2 \mathrm{H}, p$-aryl-H, 5-Pyr), 7.48 (d, J=7.7 Hz, 1H, 3-Pyr), 7.85 (td, $J=7.6,1.5 \mathrm{~Hz}, 1 \mathrm{H}, 4-\mathrm{Pyr}$ ), 9.48 (d, $J=4.4 \mathrm{~Hz}, 1 \mathrm{H}, 6-\mathrm{Pyr}$ ), ${ }^{13} \mathrm{C}\left\{{ }^{1} \mathrm{H}\right\}$ NMR $\left(\mathrm{CD}_{2} \mathrm{Cl}_{2}, T=298 \mathrm{~K}, \mathrm{ppm}\right) \delta: 23.4\left(\mathrm{CH}_{3}, i \mathrm{Pr}-\mathrm{CH}_{3}\right)$, $24.7\left(\mathrm{CH}_{3}, i \mathrm{Pr}-\mathrm{CH}_{3}\right), 28.2(\mathrm{CH}, i \mathrm{Pr}-\mathrm{CH}), 51.3\left(\mathrm{CH}_{3}, \mathrm{OCH}_{3}\right), 51.5$ $\left(\mathrm{CH}_{3}, \mathrm{OCH}_{3}\right), 55.8\left(\mathrm{CH}_{2}, \mathrm{NCH}_{2}\right), 120.2(\mathrm{CH}, \mathrm{CH}=\mathrm{CH} \mathrm{Im}), 123.3(\mathrm{CH}$ $\mathrm{CH}=\mathrm{CH} \mathrm{Im}), 123.7(\mathrm{CH}, 3-\mathrm{Pyr}), 123.7(\mathrm{CH}, m$-aryl-CH $), 124.1(\mathrm{CH}$, 5-Pyr), 129.1 (CH, p-aryl-CH), 135.5 (C, i-aryl-C), $137.5(\mathrm{CH}, 4-$ Pyr), 146.0 (C, o-aryl-C), 153.5 (C, 2-Pyr), 155.3 (CH, 6-Pyr), 170.3 (C, $C=0), 170.8$ (C, C=O), 191.1 (C, NCN). $v_{\mathrm{CO}}: 1729,1699,1680$.

Anal. Calc. for $\mathrm{C}_{31} \mathrm{H}_{37} \mathrm{~N}_{3} \mathrm{O}_{8} \mathrm{Pd}$ : C, 54.27; $\mathrm{H}, 5.44 ; \mathrm{N}, 6.12$. Found: C, $54.38 ; \mathrm{H}, 5.38$; N, 6.19\%.

4.26. $\left\{\kappa^{1}-C-[1-(P h e n y l t h i o) m e t h y l e n e-3-m e t y l] i m i d a z o l y l-2-e n e\right\}\left\{\kappa^{1}-\right.$ C-[1-(2-pyridyl)methylene-3-mesityl]imidazolyl-2ene $\operatorname{palladium}(0)$ (maleic anhydride) $(\mathbf{9})$

To a solution of $\{[1$-(2-pyridyl)methylene-3-mesityl]imidazolyl-2-ene\}palladium $(0)$ (maleic anydride) (6b) (0.064 g, $0.133 \mathrm{mmol})$ in dichloromethane $(10 \mathrm{ml})$ was added a solution of \{[1-(phenylthio)methylene-3-metyl]imidazolyl-2-ene\}silver bromide (2a) $(0.052 \mathrm{~g}, 0.133 \mathrm{mmol})$ in $10 \mathrm{ml}$ of the same solvent. Immediate precipitation of silver bromide was observed. After a half hour the reaction mixture was filtered through a Millipore filter yielding a clear solution. Reduction to small volume $(\sim 3 \mathrm{ml})$ and addition of diethylether gave the products as microcrystalline yellow solid after cooling to $0{ }^{\circ} \mathrm{C}(0.062 \mathrm{~g}, 67 \%)$. The same product was obtained starting from \{[1-(2-pyridyl)methylene-3-mesityl]imidazolyl-2-ene $\}$ silver bromide $(\mathbf{4 b})$ and $\{[1$-(phenylthio)methylene-3-metyl]imidazolyl-2-ene $(\mathbf{5 a}) .{ }^{1} \mathrm{H}$ NMR $\left(\mathrm{CD}_{2} \mathrm{Cl}_{2}\right.$, $T=298 \mathrm{~K}, \mathrm{ppm}) \delta: 1.62\left(\mathrm{~s}, 3 \mathrm{H}, p\right.$-mesityl- $\left.\mathrm{CH}_{3}\right), 1.85(\mathrm{~s}, 3 \mathrm{H}, o$-mesityl- $\left.\mathrm{CH}_{3}\right), 2.34\left(\mathrm{~s}, 3 \mathrm{H}, o\right.$-mesityl- $\left.\mathrm{CH}_{3}\right), 2.89\left(\mathrm{~s}, 3 \mathrm{H}, \mathrm{NCH}_{3}\right), 3.29,3.37$ ( $\mathrm{AB}$ system, $J=3.7 \mathrm{~Hz}, 2 \mathrm{H}, \mathrm{CH}=\mathrm{CH} \mathrm{ma}$ ) 4.81, 5.06 (AB system, $J=14.1 \mathrm{~Hz}, 2 \mathrm{H}, \mathrm{CH}_{2}-\mathrm{Pyr}$ ), $5.59,5.84$ (AB system, $J=15.5 \mathrm{~Hz}, 2 \mathrm{H}$, $\left.\mathrm{SCH}_{2}\right) 6.7(\mathrm{~d}, J=1.9 \mathrm{~Hz}, 1 \mathrm{H}, \mathrm{CH}=\mathrm{CH} \mathrm{Im}), 6.81(\mathrm{~d}, J=1.9 \mathrm{~Hz}, 1 \mathrm{H}$, $\mathrm{CH}=\mathrm{CH} \mathrm{Im}), 6.83(\mathrm{~s}, 1 \mathrm{H}, m$-mesityl-H), $6.87(\mathrm{~d}, J=1.9 \mathrm{~Hz}, 1 \mathrm{H}$, $\mathrm{CH}=\mathrm{CH} \operatorname{Im}), 6.95(\mathrm{~s}, 1 \mathrm{H}, m$-mesityl-H), $7.25(\mathrm{~d}, J=1.9 \mathrm{~Hz}, 1 \mathrm{H}$, $\mathrm{CH}=\mathrm{CH} \mathrm{Im}), 7.27-7.34(\mathrm{~m}, 6 \mathrm{H}, \mathrm{S}-\mathrm{Ph} 5 \mathrm{Pyr}) 7.41(\mathrm{~d}, J=7.9 \mathrm{~Hz}, 1 \mathrm{H}$, 3-Pyr), 7.79 (td, $J=7.7,1.9 \mathrm{~Hz}, 1 \mathrm{H}, 4-\mathrm{Pyr}), 8.63(\mathrm{~d}, J=4.0 \mathrm{~Hz}, 1 \mathrm{H}$, 6-Pyr $).{ }^{13} \mathrm{C}\left\{{ }^{1} \mathrm{H}\right\}$ NMR $\left(\mathrm{CD}_{2} \mathrm{Cl}_{2}, T=298 \mathrm{~K}\right.$, ppm) $\delta: 16.7\left(\mathrm{CH}_{3}, p\right.$-mesityl- $\left.\mathrm{CH}_{3}\right), 16.8\left(\mathrm{CH}_{3}, p\right.$-mesityl- $\left.\mathrm{CH}_{3}\right), 20.57\left(\mathrm{CH}_{3}\right.$, o-mesityl- $\left.\mathrm{CH}_{3}\right)$, $36.4\left(\mathrm{CH}_{3}, \mathrm{NCH}_{3}\right), 38.2(\mathrm{CH}, \mathrm{CH}=\mathrm{CH} \mathrm{ma}), 38.7(\mathrm{CH}, \mathrm{CH}=\mathrm{CH} \mathrm{ma})$, $54.1\left(\mathrm{CH}_{2}, \mathrm{CH}_{2}-\mathrm{Pyr}\right), 56.5\left(\mathrm{CH}_{2}, \mathrm{SCH}_{2}\right), 119.1(\mathrm{CH}, \mathrm{CH}=\mathrm{CH} \mathrm{Im})$, $121.3(\mathrm{CH}, 5-\mathrm{Pyr}), 121.9(\mathrm{CH}, \mathrm{CH}=\mathrm{CH} \mathrm{Im}), 122.4(\mathrm{CH}, \mathrm{CH}=\mathrm{CH} \mathrm{Im})$, $122.8(\mathrm{CH}, 3-\mathrm{Pyr}), 123.0(\mathrm{CH}, \mathrm{CH}=\mathrm{CH} \mathrm{Im}), 128.3(\mathrm{CH}, m$-mesityl), $128.8(\mathrm{CH}, p-\mathrm{Ph}), 129.1$ (C, p-mesityl-C), $129.2(\mathrm{CH}, o-\mathrm{Ph}), 131.6$ (C, $i-\mathrm{Ph}), 133.4(\mathrm{CH}, m-\mathrm{Ph}), 136.0$ (C, o-mesityl-C), 136.2 (C, o-mesityl-C), 137.1 (CH, 4-Pyr), 138.4 (C, $i$-mesityl-C), 149.4 (CH, 6-Pyr), 156.5 (C, 2-Pyr), 174.0 (C, C=O), 174.4 (C, C=O), 189.2 (C, NCN), 189.3 (C, NCN). IR (KBr pellet, $\mathrm{cm}^{-1}$ ) $v_{\mathrm{CO}}: 1765,1704$. Anal. Calc. for $\mathrm{C}_{42} \mathrm{H}_{43} \mathrm{~N}_{5} \mathrm{O}_{2}$ PdS: $\mathrm{C}, 63.99 ; \mathrm{H}, 5.50 ; \mathrm{N}, 8.88$. Found: $\mathrm{C}, 63.89 ; \mathrm{H}$, $5.58 ; \mathrm{N}, 8.81 \%$. 
4.27. Bis- $\left\{\kappa^{1}-C-[1-(\text { phenylthio }) \text { methylene-3-metyl]imidazolyl-2-ene }\}_{2}\right.$ palladium $(0)($ maleic anhydride) $(\mathbf{1 0})$

To a solution of $\{[1$-(phenylthio)methylene-3-metyl]imidazolyl-2-ene \}palladium $(0)$ (maleic anhydride) (5a) (0.025 g, $0.061 \mathrm{mmol})$ in dichloromethane $(10 \mathrm{ml})$ was added a solution of \{[1-(phenylthio)methylene-3-metyl]imidazolyl-2-ene\} silver bromide (2a) $(0.024 \mathrm{~g}, 0.061 \mathrm{mmol})$ in $10 \mathrm{ml}$ of the same solvent. Immediate precipitation of silver bromide was observed. After a half hour the reaction mixture was filtered through a Millipore filter yielding a clear solution. Reduction to small volume $(\sim 3 \mathrm{~mL})$ and addition of diethylether gave the product as microcrystalline yellow solids after cooling to $0{ }^{\circ} \mathrm{C}$. $(0.031 \mathrm{~g}, 82 \%) .{ }^{1} \mathrm{H} \mathrm{NMR}\left(\mathrm{CD}_{2} \mathrm{Cl}_{2}\right.$, $T=298 \mathrm{~K}, \mathrm{ppm}) \delta: 3.54(\mathrm{~s}, 2 \mathrm{H}, \mathrm{HC}=\mathrm{CH} \mathrm{ma}), 3.69\left(\mathrm{~s}, 6 \mathrm{H}, \mathrm{NCH}_{3}\right), 5.46$, 5.33 (AB system, $J=14.3 \mathrm{~Hz}, 2 \mathrm{H}, \mathrm{SCH}_{2}$ ), 6.90 (bs, $4 \mathrm{H}, \mathrm{HC}=\mathrm{CH} \mathrm{Im}$ ), 7.32-7.40 (m, $10 \mathrm{H}, \mathrm{SPh}-\mathrm{CH}) .{ }^{13} \mathrm{C}\left\{{ }^{1} \mathrm{H}\right\}$ NMR $\left(\mathrm{CD}_{2} \mathrm{Cl}_{2}, \mathrm{~T}=298 \mathrm{~K}\right.$, ppm) $\delta: 37.9\left(\mathrm{CH}_{3}, \mathrm{NCH}_{3}\right), 38.7(\mathrm{CH}, \mathrm{CH}=\mathrm{CH} \mathrm{ma}), 55.0\left(\mathrm{CH}_{2}\right.$, $\left.\mathrm{NCH}_{2}\right), 120.1(\mathrm{CH}, \mathrm{CH}=\mathrm{CH} \mathrm{Im}), 122.4(\mathrm{CH}, \mathrm{CH}=\mathrm{CH} \mathrm{Im}), 127.9(\mathrm{CH}$, SPh-CH), 129.2 (CH, SPh-CH), 131.7 (CH, SPh-CH), 174.2 (C, C=O), 188.9 (C, NCN). Anal. Calc. for $\mathrm{C}_{43} \mathrm{H}_{44} \mathrm{~N}_{4} \mathrm{O}_{2} \mathrm{PdS}_{2}$ : C, 63.03; H, 5.41; $\mathrm{N}, 6.84$. Found: C, 63.01; $\mathrm{H}, 5.48 ; \mathrm{N}, 6.79 \%$.

4.28. Equilibrium reactions between silver(I)- and palladium(0)-NHC derivatives

To a $1.5 \times 10^{-2} \mathrm{M}$ solution in $\mathrm{CD}_{2} \mathrm{Cl}_{2}$ of palladium(0)NHC complexes $\mathbf{6 a}$ or $\mathbf{6 b}$, equimolecular amounts of the silver derivatives $4 \mathbf{a}$ or $\mathbf{4 b}$ were added at RT and the ${ }^{1} \mathrm{H}$ NMR spectra of the ensuing reaction mixtures were recorded.

\subsection{Reaction between palladium(0)NHC derivatives and dmbd}

To a $1.5 \times 10^{-2} \mathrm{M} \mathrm{CD}_{2} \mathrm{Cl}_{2}$ solution of palladium(0)NHC of complexes $\mathbf{5 a}, \mathbf{5 b}, \mathbf{6 a}$ or $\mathbf{6 b}$ a stoichiometric amount of dmbd ([complex]: [dmbd] $\approx 1: 2$ ) was added at $253 \mathrm{~K}$ and the ${ }^{1} \mathrm{H}$ NMR spectra of the ensuing reaction mixtures were recorded. In the RT ${ }^{1} \mathrm{H}$ and ${ }^{13} \mathrm{C}$ NMR spectra in $\mathrm{CDCl}_{3}$ of the reaction mixture between $\mathbf{6 a}$ and dmbd the formation of species 12 was observed. ${ }^{1} \mathrm{H}$ NMR $\left(\mathrm{CDCl}_{3}, T=298 \mathrm{~K}, \mathrm{ppm}\right) \delta: 3.40\left(\mathrm{~s}, 3 \mathrm{H}, \mathrm{OCH}_{3}\right), 3.42\left(\mathrm{~s}, 3 \mathrm{H}, \mathrm{OCH}_{3}\right)$, 3.68(s, 3H, $\left.\mathrm{OCH}_{3}\right), 3.72\left(\mathrm{~s}, 3 \mathrm{H}, \mathrm{NCH}_{3}\right), 3.73\left(\mathrm{~s}, 3 \mathrm{H}, \mathrm{OCH}_{3}\right), 5.07$ (bd, $\left.1 \mathrm{H}, \mathrm{NCH}_{2}\right), 5.83$ (bd, $\left.1 \mathrm{H}, \mathrm{NCH}_{2}\right), 6.78(\mathrm{~d}, J=1.5 \mathrm{~Hz}, 1 \mathrm{H}, \mathrm{CH}=\mathrm{CH}$ $\operatorname{Im}), 7.08(\mathrm{~d}, J=1.5 \mathrm{~Hz}, 1 \mathrm{H}, \mathrm{CH}=\mathrm{CH} \mathrm{Im}$ ), 7.33 (ddd, $J=7.7,5.4$, $1.0 \mathrm{~Hz}, 1 \mathrm{H}, 5$-Pyr), 7.56 (d, $J=7.7 \mathrm{~Hz}, 1 \mathrm{H}, 3-\mathrm{Pyr}$ ), 7.84 (td, $J=7.7$, $1.7 \mathrm{~Hz}, 1 \mathrm{H}, 4-\mathrm{Pyr}), 8.66$ (d, $J=5.4 \mathrm{~Hz}, 1 \mathrm{H}, 6-\mathrm{Pyr}),{ }^{13} \mathrm{C}\left\{{ }^{1} \mathrm{H}\right\} \mathrm{NMR}$ $\left(\mathrm{CDCl}_{3}, T=298 \mathrm{~K}, \mathrm{ppm}\right) \delta: 37.4\left(\mathrm{CH}_{3}, \mathrm{NCH}_{3}\right), 50.3\left(\mathrm{CH}_{3}, \mathrm{OCH}_{3}\right)$, $50.9\left(\mathrm{CH}_{3}, \mathrm{OCH}_{3}\right), 51.2\left(\mathrm{CH}_{3}, \mathrm{OCH}_{3}\right), 51.2\left(\mathrm{CH}_{3}, \mathrm{OCH}_{3}\right), 56.5\left(\mathrm{CH}_{2}\right.$, $\left.\mathrm{NCH}_{2}\right), 121.3(\mathrm{CH}, \mathrm{CH}=\mathrm{CH} \operatorname{Im}), 121.4(\mathrm{CH}, \mathrm{CH}=\mathrm{CH} \mathrm{Im}), 124.1(\mathrm{CH}$, 5-Pyr), 124.7 (CH, 3-Pyr), 138.5 (CH, 4-Pyr), 141.1 (C, C=C), 148.4 (C, C=C), 152.7 (C, 6-Pyr), $154.1(\mathrm{CH}, 2-\mathrm{Pyr}), 164.3(\mathrm{C}, \mathrm{C}=\mathrm{O})$, $166.1(C, C=0), 175.1(C, C=0), 175.7(C, C=0), 177.5(C, C=C)$, 180.5 (C, NCN). Anal. Calc. for $\mathrm{C}_{22} \mathrm{H}_{23} \mathrm{~N}_{3} \mathrm{O}_{8} \mathrm{Pd}$ : C, 46.86; H, 4.11; N, 7.45. Found: C, 46.53; H, 4.05; N, 7.38\%.

\section{Appendix A. Supplementary material}

Supplementary data associated with this article can be found, in the online version, at http://dx.doi.org/10.1016/j.ica.2012.04.018.

\section{References}

[1] J.C. Jeffrey, T.B. Rauchfuss, Inorg. Chem. 18 (1979) 2658.

[2] P. Braunstein, F. Naud, Angew. Chem., Int. Ed. 40 (2001) 680

[3] (a) A. Bader, E. Lindner, Coord. Chem. Rev. 108 (1991) 27;

(b) C.S. Slone, D.A. Weinberger, C.A. Mirkin, Prog. Inorg. Chem. 48 (1999) 233; (c) S.W. Kohl, L. Weiner, L. Schwartsburd, L. Konstantinovski, L.J.W. Shimon, Y. Ben-David, M.A. Iron, D. Milstein, Science 324 (2009) 74;

(d) M. Feller, E. Ben-Ari, M.A. Iron, Y. Diskin-Posner, G. Leitus, L.J.W. Shimon, L.
Konstantinovski, D. Milstein, Inorg. Chem. 49 (2010) 1615;

(e) J.L. van der Vlugt, E.A. Pidko, D. Vogt, M. Lutz, A.L. Spek, Inorg. Chem. 48 (2009) 7513;

(f) J.I. van der Vlugt, M.A. Siegler, M. Janssen, D. Vogt, A.L. Spek, Organometallics 28 (2009) 7025;

(g) R. Lindner, B. van der Bosch, M. Lutz, J.N.H. Reek, J.I. van der Vlugt, Organometallics 30 (2011) 499

(h) M.T. Whited, R.H. Grubbs, Acc. Chem. Res. 42 (2009) 1607;

(i) M. Gagliardo, N. Selander, N.C. Mehendale, G. van Koten, R.J.M. Klein Gebbink, K.J. Szabó, Chem. Eur. J. 14 (2008) 4800;

(j) I. Moreno, R. San Martin, B. Inés, M.T. Herrero, E. Dominguez, Curr. Org. Chem. 13 (2009) 878.

(k) D.M. Spasyuk, D. Zargarian, A. van der Est, Organometallics 28 (2009) 6531; (1) S. Bonnet, J. Li, M.A. Siegler, L.S. von Chrzanowski, A.L. Spek, G. van Koten, R.J.M. Klein Gebbink, Chem. Eur. J. 15 (2009) 3340;

(m) V.A. Kozlov, D.V. Aleksanyan, Y.V. Nelyubina, K.A. Lyssenko, A.A. Vasil'ev, P.V. Petrovski, I.L. Odinets, Organometallics 29 (2010) 2054;

(n) D.M. Spasyuk, D. Zargarian, Inorg. Chem. 49 (2010) 6203;

(o) J.-L. Niu, Q.-T. Chen, X.-Q. Hao, Q.-X. Zhao, J.-F. Gong, M.-P. Song, Organometallics 29 (2010) 2248;

(p) B.-S. Zang, W. Wang, D.D. Shao, X.-D. Hao, J.-F. Gong, M.-P. Song, Organometallics 29 (2010) 2579;

(q) M.A. Siegler, M. Lutz, A.L. Spek, R.J.M. Klein Gebbink, G. van Koten, Adv. Synth. Catal. 352 (2010) 2474.

[4] A.J. Arduengo, Acc. Chem. Res. 32 (1999) 913. and refs. therein.

[5] (a) H.M. Lee, C.-C. Lee, P.-Y. Cheng, Curr. Org. Chem. 11 (2007) 1491;

(b) A.T. Normand, K.J. Cavell, Eur. J. Inorg. Chem. (2008) 2781;

(c) M.C. Jahnke, T. Pape, F.E. Hahn, Eur. J. Inorg. Chem. (2009) 1960;

(d) D. Meyer, M.A. Taige, A. Zeller, K. Hohlfeld, S. Ahrens, T. Strassner, Organometallics 28 (2009) 2142;

(e) A.R. Chianese, P.T. Bremer, C. Wong, R.J. Reynes, Organometallics 28 (2009) 5244 ;

(f) W.W.N. O, A.J. Lough, R.H. Morris, Organometallics 28 (2009) 6755;

(g) S. Warsink, P. Hauwert, M.A. Siegler, A.L. Spek, C.J. Elsevier, Appl. Organomet. Chem. 23 (2009) 225;

(h) S. Warsink, S.Y.D. Boer, L.M. Jongens, C.-F. Fu, S.-T. Liu, J.-T. Chen, M. Lutz, A.L. Spek, C.J. Elsevier, Dalton Trans. (2009) 7080;

(i) C. Lu, S. Gu, W. Chen, H. Qiu, Dalton Trans. 39 (2010) 4198;

(j) S. Warsink, R.M. Drost, M. Lutz, A.L. Spek, C.J. Elsevier, Organometallics 29 (2010) 3109 .

[6] (a) L. Canovese, G. Chessa, F. Visentin, P. Uguagliati, Coord. Chem. Rev. 248 (2004) 945 ;

(b) L. Canovese, F. Visentin, Inorg. Chim. Acta 363 (2010) 2375.

[7] (a) A. Ros, D. Monge, M. Alcarazo, E. Álvarez, J.M. Lassaletta, R.R. Fernàndez, Organometallics 25 (2006) 6039;

(b) S.J. Roseblade, A. Ros, D. Monge, M. Alcarazo, E. Álvarez, J.M. Lassaletta, R.R. Fernàndez, Organometallics 26 (2007) 2570;

(c) E. Kluser, A. Neels, M. Albrecht, Chem. Commun. (2006) 4495;

(d) J. Wolf, A. Labande, J-C. Daran, R. Poli, Eur. J. Inorg. Chem. (2007) 5069.

(e) S. -T Liu, C.-I. Lee, C.--F. Fu, C.-H. Chen, Y.-H. Liu, C.J. Elsevier, S.-M. Peng, J.-T. Chen, Organometallics 28 (2009) 6597;

(f) C. Fliedel, A. Sabbatini, P. Braunstein, Dalton Trans. 39 (2010) 8820

[8] (a) D.S. Mc Guiness, K.J. Cavell, Organometallics 19 (2000) 741;

(b) A.A.D. Tulloch, A.A. Danopoulos, S. Kleinhenz, M.E. Light, M.B. Hursthouse,

G. Eastham, Organometallics 20 (2001) 2027;

(c) S. Winston, N. Stylianides, A.A.D. Tulloch, J.A. Wright, A.A. Danopoulos, Polyhedron 23 (2004) 2813;

(d) X. Wang, S. Liu, G.-X. Jin, Organometallics 23 (2004) 6002;

(e) M. Yigit, B. Yigit, I. Ozdemir, E. Cetinkaya, B. Cetinkaya, Appl. Organomet. Chem. 20 (2006) 322;

(f) F. Zeng, Z. Yu, J. Org. Chem. 71 (2006) 5274;

(g) L. Mercs, G. Labat, A. Neels, A. Ehlers, M. Albrecht, Organometallics 25 (2006) 5648 ;

(h) Z. Xi, X. Zhang, W. Chen, S. Fu, D. Wang, Organometallics 27 (2007) 6636; (i) Z. Xi, B. Liu, W. Chen, J. Org. Chem. 73 (2008) 3954;

(j) X. Zhang, Z. Xi, A. Liu, W. Chen, Organometallics 27 (2008) 4401;

(k) X. Zhang, B. Liu, A. Liu, W. Xie, W. Chen, Organometallics 28 (2009) 1336;

(l) Z. Xi, B. Liu, V. Lu, W. Chen, Dalton Trans. (2009) 7008;

(m) B. Liu, A. Liu, Y. Zhou, W. Chen, Organometallics 29 (2010) 1457;

(n) P.L. Chiu, C.-L. Lai, C.-F. Chang, C.-H. Hu, H.M. Lee, Organometallics 24 (2005) 6169.

[9] J. Liu, J. Chen, J. Zhao, Y. Zhao, H. Zhang, Synthesis (2003) 2661.

[10] (a) A.A.D. Tulloch, A.A. Danopoulos, S. Winston, S. Kleinhenz, G. Eastham, J. Chem. Soc., Dalton Trans. (2000) 4499;

(b) C. -Y Wang, Y-H. Liu, S.-M. Peng, S.-T. Liu, J. Organomet. Chem. 691 (2006) 4012.

[11] (a) J.C. Garrison, W.J. Youngs, Chem. Rev. 105 (2005) 3978;

(b) I.J.B. Lin, C.S. Vasam, Coord. Chem. Rev. 251 (2007) 642;

(c) S. Warsink, C.M.S. Aubel, J.J. Weigand, S.-T. Liu, C.J. Elsevier, Eur. J. Inorg. Chem. (2010) 5556

[12] D.S. McGuinness, K.J. Cavell, B.W. Skelton, A.H. White, Organometallics 18 (1999) 1596.

[13] (a) K.J. Cavell, D.J. Stufkens, K. Vrieze, Inorg. Chim. Acta 47 (1981) 67; (b) S. Warsink, I.-H. Chang, J.J. Weigand, P. Hauwert, J.-T. Chen, C.J. Elsevier, Organometallics 29 (2010) 4555. 
[14] (a) L. Canovese, F. Visentin, G. Chessa, P. Uguagliati, C. Santo, A. Dolmella, Organometallics 24 (2005) 3297;

(b) L. Canovese, G. Chessa, F. Visentin, Inorg. Synth. (2006), submitted for publication.

[15] (a) V. Lucchini, G. Borsato, L. Canovese, C. Santo, F. Visentin, A. Zambon, Inorg. Chim. Acta 362 (2009) 2715;

(b) L. Canovese, V. Lucchini, C. Santo, F. Visentin, A. Zambon, J. Organomet. Chem. 642 (2002) 58

[16] M. Frøseth, D.S. Netland, K.W. Törnroos, A. Dhindsa, M. Tilset, Dalton Trans. (2005) 1664.

[17] C. Fliedel, P. Braunstein, Organometallics 29 (2010) 5614.

[18] J.-Y. Lee, P.-Y. Cheng, Y.-H. Tsai, G.-R. Lin, S.-P. Liu, M.-H. Sie, H.M. Lee, Organometallics 29 (2010) 3901.

[19] K.J. Cavell, Organometallics 25 (2006) 4155.

[20] (a) M. J. Frisch, G. W. Trucks, H. B. Schlegel, G. E. Scuseria, M. A. Robb, J. R. Cheeseman, G. Scalmani, V. Barone, B. Mennucci, G. A. Petersson, H. Nakatsuji, M. Caricato, X. Li, H. P. Hratchian, A. F. Izmaylov, J. Bloino, G. Zheng, J. L. Sonnenberg, M. Hada, M. Ehara, K. Toyota, R. Fukuda, J. Hasegawa, M. Ishida, T. Nakajima, Y. Honda, O. Kitao, H. Nakai, T. Vreven, J. A. Montgomery Jr., J. E. Peralta, F. Ogliaro, M. Bearpark, J. J. Heyd, E. Brothers, K. N. Kudin, V. N. Staroverov, R. Kobayashi, J. Normand, K. Raghavachari, A. Rendell, J. C. Burant, S. S. Iyengar, J. Tomasi, M. Cossi, N. Rega, J. M. Millam, M. Klene, J. E. Knox, J. B. Cross, V. Bakken, C. Adamo, J. Jaramillo, R. Gomperts, R. E. Stratmann, O. Yazyev, J. Austin, R. Cammi, C. Pomelli, J. W. Ochterski, R. L. Martin, K. Morokuma, V. G. B.Zakrzewski, G. A. Voth, P. Salvador, J. J. Dannenberg, S. Dapprich, A. D. Daniels, O. Farkas, J. B. Foresman, J. V. Ortiz, J. Cioslowski, D. J. FoX, GAUSSIAN 09, Revision A.1, Gaussian Inc., Wallingford CT, 2009.;

(b) F. Weigend, R. Ahlrichs, Phys. Chem. Chem. Phys. 7 (2005) 3297; (c) Y. Zhao, D.G. Truhlar, Theor. Chem. Acc. 120 (2008) 215.

[21] (a) L. Canovese, F. Visentin, G. Chessa, P. Uguagliati, C. Levi, A. Dolmella, Organometallics 24 (2005) 5537;

(b) A. Holuigue, J.M. Ernsting, F. Visentin, C. Levi, L. Canovese, C.J. Elsevier, Organometallics 27 (2008) 4050; (c) L. Canovese, F. Visentin, G. Chessa, C. Santo, C. Levi, P. Uguagliati, Inorg. Chim. Commun. 9 (2006) 388.

[22] M.N. Burnett, C.K. Johnson, ORTEP III, Report ORNL-6895, Oak Ridge National Laboratory, Oak Ridge, TN, 1996.

[23] (a) A.M. Kluwer, C.J. Elsevier, M. Bühl, M. Lutz, A.L. Spek, Angew. Chem., Int. Ed. 42 (2003) 3501;

(b) K. Selvakumar, M. Valentini, P.S. Pregosin, A. Albinati, Organometallics 18 (1999) 4591:

(c) R. van Asselt, C.J. Elsevier, W.J.J. Smeets, A.L. Spek, Inorg. Chem. 33 (1994) 1521 ;

(d) C. Foltz, M. Enders, S. Bellemin-Laponnaz, H. Wadepohl, L.H. Gade, Chem. Eur. J. 13 (2007) 5994;

(e) L. Canovese, F. Visentin, G. Chessa, P. Uguagliati, A. Dolmella, J. Organomet. Chem. 601 (2000) 1;

(f) S. Warsink, P. Hauwert, M.A. Siegler, A.L. Spek, C.J. Elsevier, Appl. Organomet. Chem. 23 (2009) 225;

(g) H. Kooijman, A.L. Spek, R. van Belzen, C.J. Elsevier, Acta Crystallogr., Sect. C 53 (1997) 1593;

(h) R. Zalubovskis, A. Bouet, E. Fjellander, S. Constant, D. Linder, A. Fisher, J. Lalour, T. Privalov, C. Moberg, J. Am. Chem. Soc. 130 (2008) 1845.

[24] Z. Otwinowski, W. Minor, in: C.W. Carter, R.M. Sweet (Eds.), Methods in Enzymology Part A, vol. 276, Academic Press, London, 1997, pp. 307-326.

[25] R.H. Blessing, Acta Crystallogr., Sect. A 51 (1995) 33.

[26] A. Altomare, M.C. Burla, M. Camalli, G.L. Cascarano, C. Giacovazzo, A. Guagliardi, A.G. Moliterni, G. Polidori, R. Spagna, J. Appl. Crystallogr. 32 (1999) 115.

[27] G.M. Sheldrick, SHELX-97 Program for Crystal Structure Refinement, University of Gottingen, Germany, 1997.

[28] M. Nardelli, J. Appl. Crystallogr. 28 (1995) 659.

[29] L.J. Farrugia, J. Appl. Crystallogr. 32 (1999) 837.

[30] T. Ukai, H. Kawazura, Y. Ishii, J.J. Bonnet, J.A. Ibers, J. Organomet. Chem. 65 (1974) 253.

[31] K. Itoh, F. Ueda, K. Hirai, Y. Ishii, Chem. Let. (1977) 877. 